Research Article

\title{
Relationship between Thermal Variance and Hatchery Estimates of Fertility in a Multispecies Assemblage of Anadromous Salmonids in Response to Managed Flows
}

Robert M. Sullivan ${ }^{1,}{ }^{*}$, John P. Hileman ${ }^{2}$

1. California Department of Fish and Wildlife, Region 1, Wildlife/Lands Program, P.O. Box 1185 Weaverville, California 96093; E-Mail: robert.sullivan@wildlife.ca.gov

2. California Department of Fish and Wildlife, Region 1, Fisheries Program, Trinity River Project, P.O. Box 1185, Weaverville, California 96093; E-Mail: John.Hileman@wildlife.ca.gov

* Correspondence: Robert M. Sullivan; E-Mail: robert.sullivan@wildlife.ca.gov

Academic Editor: Petros Ganatsas

Special Issue: Environmental Monitoring and Protection of Inland River

Adv Environ Eng Res

2022, volume 3, issue 1

doi:10.21926/aeer.2201009
Received: November 15, 2021

Accepted: February 13, 2022

Published: February 22, 2022

\begin{abstract}
Our study sought to identify a regional explanation for declining fertility in stocks of cooccurring salmonids in the upper Trinity River, northern California, USA. We focused on evaluating the relationship between thermal variance in river water and hatchery-measured estimates of female fertility as a function of highly managed annual flow regimes. We evaluated annual and seasonal variation in volume of flow and water temperature in response to managed flows associated with annual in-river restoration actions. We assessed the relationship between flow-mediated thermal variance in river water and estimates of fertility in hatchery parental bloodstock in a multi-species assemblage of co-occurring anadromous salmonids. Results of our study found: 1) significant differences between flow-types in flow volume and the thermal variance evaluated with reference to the historical run-time schedule of each taxon; 2) significant differences among species-specific flow-types for each environmental variable measured; 3 ) significant declines in the averaged daily number of total
\end{abstract}

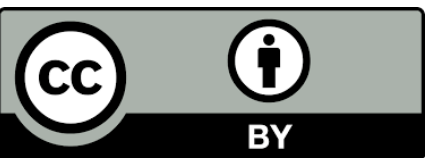

(C) 2022 by the author. This is an open access article distributed under the conditions of the Creative Commons by Attribution License, which permits unrestricted use, distribution, and reproduction in any medium or format, provided the original work is correctly cited. 
eggs harvested in all species except steelhead; 4) significant differences in the estimates of fertility for all species-specific flow-types, in which $83.3 \%$ of planned pairwise comparisons differed between flow-types for each taxon; 5) significant declines in the annual estimates of fertility in all species; and 6) significant negative correlations between species-specific estimates of fertility and thermal variance in water temperature. Overall, our findings suggest that increased temperature variation from managed flows may reduce estimates of fertility in hatchery-spawned salmonids; and that concordant patterns in response to thermal variance in species with divergent life histories may in part be a function of anthropogenic altered flow regimes on ecosystem processes and the fisheries resources they support.

\section{Keywords}

Altered flow regime; anthropogenic; river; artificial spawning; restoration; water temperature

\section{Introduction}

Numerous laboratory and in-river field studies have demonstrated that thermal variance in water temperature is a critical factor affecting all aspects of adapted life history expressions in fish (Table S1). These studies demonstrate the potential for both direct and indirect effects of extreme fluctuations in water temperature on fertility, egg development, growth, timing of migration, timing of spawning [1]. Natural thermal regimes vary widely in complex and dynamic geomorphologically and topographically diverse river systems in both time and space. However, although natural environmental influences determine river flow and its effect on water temperature in unregulated rivers, these variables may be greatly altered by hydroelectric dam operations that redistribute water and regulate flow in highly managed riverine systems [2, 3]. Anthropogenically-induced variability in hydrology and its impact on the thermal regimes of major rivers is a critical factor affecting the physiology, ecology, and life history strategies of resident salmonids [3-8]. The timing, variance, and magnitude of reservoir water releases have had dramatic effects on temperature regimes in watersheds and highly managed river systems [9-11]. Knowledge of the thermal regime of a river is critical to effective management of environmental flow, as well as understanding the potential impacts of dam-generated hydroelectric power on freshwater ecology and conservation of riverine fisheries resources; a topic recently reviewed and illustrated by Geist [3].

Water temperature models, with and without in-stream flow requirements suggest a clear relationship between river water temperatures and rate of flow [12]. This phenomenon directly influences the incubation temperature regime, which in turn influences the phenology and survival in embryos and alevins ([13]; Table S1). For example, Weinhemier et al. [14] showed that peak flows during incubation were strongly and negatively related to egg survival, and warmer temperatures were related to early emergence and timing of migration. Beckman et al. [15] identified genetic changes that affect timing of emergence under a common thermal regime, in which a genetic response and local adaptation to riverine thermal regimes may result from both mean and variance measures in water temperature. Similarly, highly modified natural flow regimes may cause life history strategies of fish assemblages, historically adapted to regional habitat templates, to be significantly altered downstream of dams in only a few decades owing to anthropogenic 
modifications in timing of stream flow [16-19]. Because salmonid populations have evolved in response to the temperature regime they historically used for migration and spawning, deviations from the normal pattern can affect survival [20]. Species with a narrow thermal "niche" are particularly vulnerable to alterations in water temperature regimes [21]; and taxa adapted to coldwater habitats may be especially vulnerable to the increases in temperature that commonly result from human influences [22, 23]. Thus, it is critical that fisheries resource managers understand how variation in thermal physiology yields population-specific thermal performance [24].

Significantly, temporal variability in riverine water temperature has important biological and ecological consequences as a function of nonlinear relationships in species-specific physiological responses [25-27]. Yet adaptive management and conservation planning frequently only consider the effects of spatial heterogeneity in thermal variance. These efforts rarely reflect on the complexity of temporal heterogeneity $[28,29]$ and its effect on the complex interactions between abiotic and biotic factors that relate time and resource use [30, 31]. While spatial priorities generally derive from first-order temperature metrics (i.e., use of only mean values) traditional degree-day models are mostly insufficient to explain the effects of mean water temperature on the timing of life history strategies at regional scales $[12,27]$. Evidence continues to mount that biological and ecological reactions to thermally fluctuating environments will differ from expectations based on mean temperature alone [26]. This is because conventional analyses tend to oversimplify modeling by ignoring critical elements of thermal diversity by placing greater emphasis on simplistic lethal maxima underlying most water quality standards [32]. For example, in fisheries management use of landscape models to predict future distributions of species generally employ temperature means but not fluctuations in thermal variability [24, 33-35]. Accentuating this complexity are alterations in the "natural" thermal variance originating from extrinsically managed hydrographs at seasonal, weekly, and daily scales as a function of reservoir operations, dam discharges, water diversions, and actions associated with in-river geomorphological restoration [3, 36].

Knowledge of fish productivity in altered riverine systems is particularly important for management of anadromous salmonids given that native stocks have experienced significant declines due to regional environmental and anthropogenic factors [37-41]. Throughout the Central Valley of California, populations of anadromous Chinook Salmon and steelhead have experienced dramatic declines in the last century owing to construction of many water impoundments and diversions on many riverscapes. These alterations changed the historic flow and thermal regimes, resulting in thermally coupled deviations in fish development, growth, health, distribution, and survival [9]. In northern California, discharge of flows from Lewiston Dam into the upper Trinity River involves complex issues affected by political, economic, environmental, and biological factors. Depending upon the configuration of the hydrograph the thermal characteristics of the discharge can vary widely and must be considered relative to the potential effects on all aquatic biota [42]. In the upper-most cold-water reach of the Trinity River accessible to spawning salmonids there have been considerable and consistent fluctuations in the volume of flow since 2003. Consistent annual alterations of the "normalized" post-dam flow are in large measure a function of in-river managed geomorphic restoration actions [43]. Recent time series modeling suggests that subcomponents of the historical post-dam flow volume, keyed to geomorphologic restoration actions, significantly misrepresent the time series characteristics, seasonal-trend decomposition patterns, and forecast accuracy compared to the baseline pre-restoration time series hydrographic model [36]. These activities also have altered run-timing in anadromous hatchery- and natural-origin spawning 
salmonids Chinook Salmon, Coho Salmon, steelhead, and local migration patterns of nonanadromous Brown Trout and Klamath Small-scale Suckers relative to the historical post-dam pattern [44-46]. All of these species of salmonids spawn predominantly within the first $15 \mathrm{~km}$ of the mainstem below Lewiston Dam; and Chinook Salmon now increasingly spawn down-river and outside newly constructed mainstem restoration sites [47].

The purpose of our study focused on evaluating the relationship between thermal variance in river water and hatchery-measured estimates of female fertility as a function of anthropogenic altered annual flow. The question we pose is this. "What is the relationship between estimates of fertility in artificially propagated hatchery parental brood-stock and thermal variance in river water as a function of highly managed annual flow regimes?" To address this question, we: 1) describe and evaluate annual and seasonal variation in flow volume and water temperature as a function of continuous flow management since 2003; and 2) assess the pattern and relationship between flowmediated water temperature and fertility within a multi-species assemblage of co-occurring anadromous salmonids. Understanding the relationship between flow management, temperature, and measures of fertility may help researchers improve their predictions of how temperature affects various aspects of species-specific phenology $[7,48]$ in salmonid life history data within both a controlled hatchery environment and an in-river setting.

\section{Materials and Methods}

\subsection{Study Area and Background on Managed Flows}

Our study focused on the upper-most reach of the Trinity River in northwest California, USA (Figure 1). Trinity and Lewiston dams were constructed in the early 1960s. Trinity Dam creates Trinity Reservoir that stores up to $3,022 \mathrm{~m}^{3}$ of water. Lewiston Reservoir formed by Lewiston Dam is located $11.8 \mathrm{~km}$ downstream of Trinity Dam (river kilometer [rkm] 179.8). It functions as a reregulating reservoir for flow into the Trinity River and as a source of water diverted to the Sacramento River Basin [49]. Lewiston Dam is the uppermost limit of anadromous fisheries on the Trinity River. Administratively, the upper Trinity River (mainstem) is the section of the river from the confluence of the North Fork Trinity River $63.1 \mathrm{rkm}$ upstream to Lewiston Dam. The Trinity River Hatchery (henceforth called "hatchery") is immediately below Lewiston Dam. 


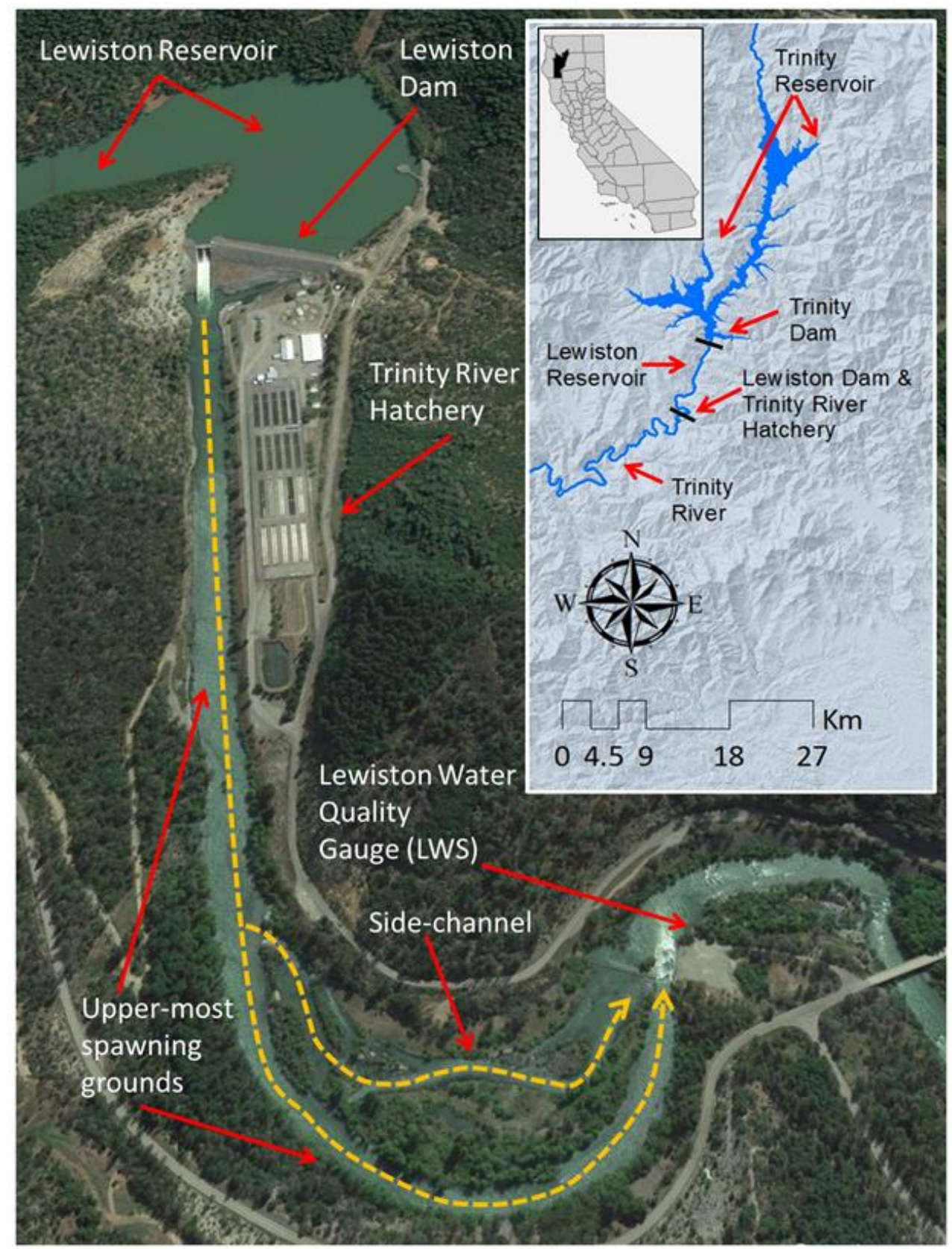

Figure 1 Map showing Trinity County (shaded black area in CA map), Trinity and Lewiston reservoirs and dams, Trinity River Hatchery; the upper-most limit of the primary traditional natural area spawning $1.7 \mathrm{rkm}$ downstream of the hatchery, including sidechannel (dashed gold-colored line); and the Lewiston Water Quality gauge (LWS; https://earth.google.com/web). Black bars in inset map indicated where Trinity and Lewiston dams are located.

In 2000, the United States Department of Interior (USDI), Record of Decision (henceforth called the "ROD") outlined a plan for restoration of the mainstem Trinity River and its fish and wildlife populations. The ROD was based 20 years of studies of the Trinity River and its fishery resources that culminated in the Trinity River Flow Evaluation Final Report [43, 49, 50], which recommended that high summer flows were necessary to maintain or restore salmon habitat and populations on 
the Trinity River. In 2000 the ROD directed that $~ 50 \%$ of the water would remain in the river (not be diverted to Central Valley). As a result of the ROD and the TRFES, the Trinity River Restoration Program [43] was formally established in 2002 to recommend how water was to be released for restoration of the mainstem Trinity River and its fisheries resources. The ROD defined five water year-types along with a minimum volume of water to be released into the Trinity River annually in accordance with the annual flow recommendations. The term "water year" defined by the United States Geological Survey is "the 12-month period 1 October (of any given year) through 30 September of the following year" (https://water.usgs.gov/nwc/explain data.html).

The strategy for restoration of the mainstem Trinity River included: 1) flow management through manipulation of the annual hydrograph, 2) mechanical channel rehabilitation, 3) sediment management, 4) watershed restoration, 5) infrastructure improvements, 6) adaptive environmental assessment and monitoring, and 7) environmental compliance and mitigation [43]. These actions were intended to clean spawning gravels, build gravel bars, scour sand out of pools, provide adequate temperature and habitat conditions for fish and wildlife at different life stages, control riparian vegetation, and perform other ecological functions. From 2003 through 2019, total restoration releases have included flows for: 1) restoration, 2) late summer pulse flows, and 3) Tribal Ceremonial Boat Dances (Figure 2A and Table S2). Tribal flows occur only in odd years, just prior to any pulsed augmentation flows. Since 2003 they have amounted to $\sim 0.65 \%$ of the total annual release into the Trinity River. Pulsed augmentation flows generally tier-off the trailing ends of ceremonial flows [44-46]. 


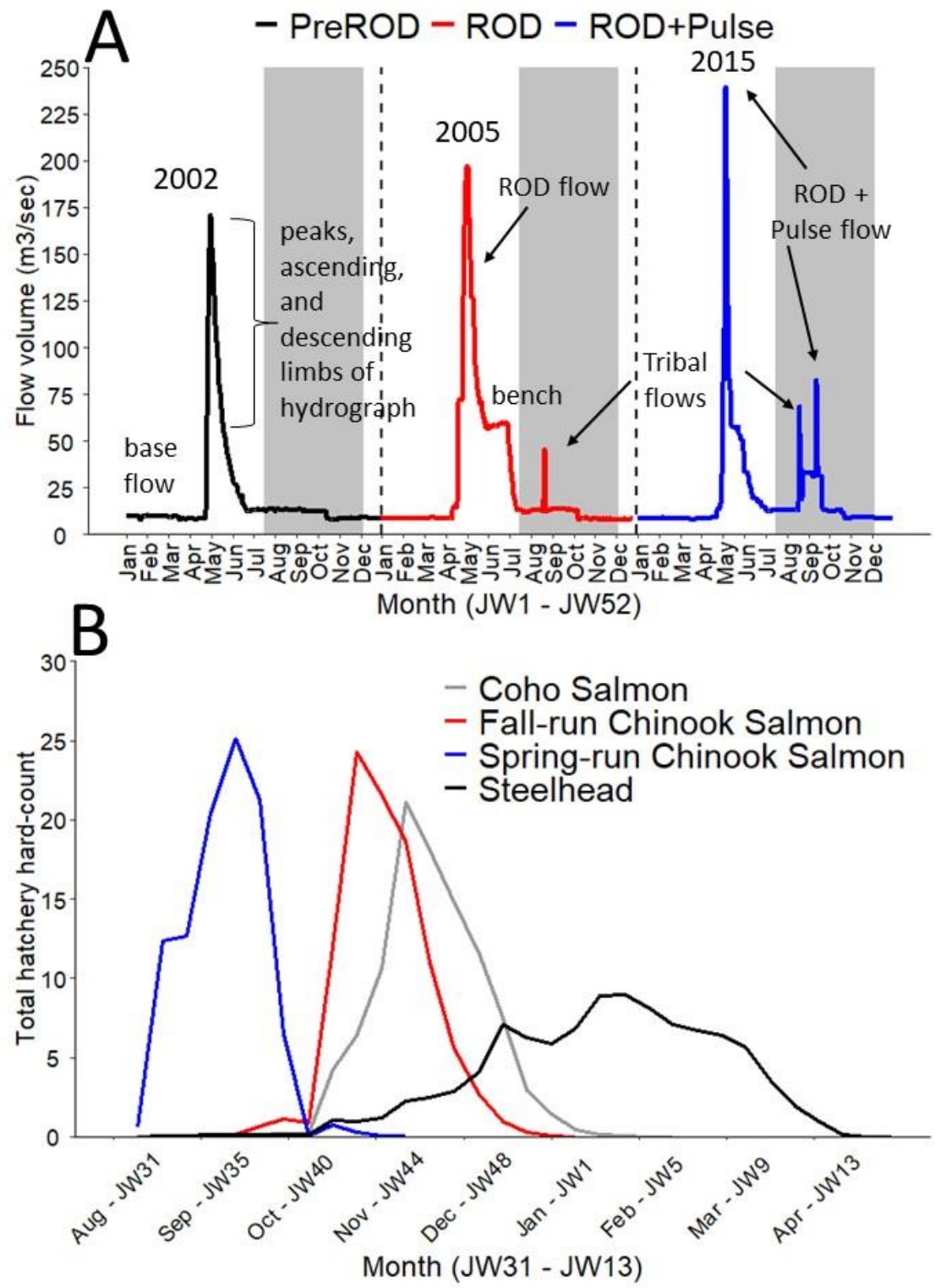

Figure $2 \mathrm{~A}$ ) Representative examples of hydrographs of the three different flow-types (PreROD [2002], ROD [2005], ROD + Pulse [2015]). Tribal Ceremonial Boat Dance flows occur in odd years. Hydrographs associated with ROD and ROD + Pulse flows were typically implemented between Julian week JW13 and JW40. Shaded colored areas correspond to an overlay of the run-time presence of each species in the upper river for each flow-type example. B) Historical seasonal (month / JW) run-time distribution as determined by total hard-counts of Coho Salmon (1990 - 2018), spring- and fall-run Chinook Salmon (1994 - 2018), and steelhead (1990 -2018) obtained from Trinity River Hatchery.

\subsection{Characteristics of Baseline and Managed Hydrographs}

There are no comprehensive or systematic baseline data for pre-dam hydrographic or water temperature for the Trinity River below Lewiston Dam. Therefore, we equate "baseline" post-dam flows (henceforth called "Pre-ROD flows") to flow releases that occurred after such data became 
available from 1994 to the present. Pre-ROD flows (1994 - 2018) are those that occurred after construction of the Trinity and Lewiston dams yet prior to implementation of annually managed hydrographs or pulsed flow augmentations, except on rare occasions due to an "emergency-ofdams" release because of abundant rain in combination with snow melt, as occurred in 1974. PreROD flows generally lasted $~ 52.4$ days from late April to late July (range 28.0 - 81.0 days) and averaged $\sim 119.6 \mathrm{~m}^{3} / \mathrm{second}$ (range $62.3-192.3 \mathrm{~m}^{3} / \mathrm{sec}$ ) of flow the peak of the hydrograph (Figure 2A; [44, 45]). In contrast, from 2003 to $2018 \sim 25.7 \mathrm{~km}^{3}$ of water was released from Lewiston Reservoir; of which $50.6 \%$ was released down the Trinity River and $49.4 \%$ was diverted to the Sacramento River. Of flow released down the Trinity River $\sim 12.4 \mathrm{~km}^{3} /$ year $\left(\bar{x}=0.77 \mathrm{~km}^{3}\right)$ was allocated for in-river geomorphic restoration purposes (Table S2; [46]).

This restoration flow regime (henceforth called "ROD flows") generally occurs from late April to August (Table S2). Timing, magnitude, shape, and duration of each ROD flow hydrograph varies annually depending upon the specific intent of the management action [43]. Average duration of each ROD flow was 89.8 days from mid-April to early August (62.0 - 112.0 days) and averaged $221.9 \mathrm{~m}^{3} / \mathrm{second}\left(124.9-328.6 \mathrm{~m}^{3} / \mathrm{sec}\right)$ of flow at the peak of the hydrograph [46]. Supplemental late summer pulse-flow augmentations have also occurred in 2003 and 2004, from 2012 to 2016, and in 2018. Implementation of these late summer pulsed flow augmentations were intended to cue upstream seasonal migration of Chinook Salmon out of the lower Klamath River to potentially reduce risk of density dependent epizootic of the ciliate parasite Ichthyophthirius multifiliis. Average duration of pulsed flows approximated 28.3 days from mid-August to late September (11.0 - 40.0 days) and averaged $\sim 61.1 \mathrm{~m}^{3} / \mathrm{second}\left(35.3-97.0 \mathrm{~m}^{3} / \mathrm{sec}\right)$ of flow the top of the hydrograph (Figure 2A; [46]). Importantly, we note that previously each pulsed flow event was also accompanied by a single ROD flow hydrograph (henceforth called ROD + Pulse flows) beginning in 2003. Thus, for each Pulse + ROD flow, the effects of each pulsed augmentation are not totally independent from the effects of its companion ROD flow.

\subsection{Data Collection}

Representative examples of each annual flow-type and distinguishing characteristics, and the seasonal run-time schedule specific to each species based on hatchery hard-counts of individual fish are illustrated in Figure 2A and Figure 2B. Except for analyses of annual variation (1994 - 2018) in each environmental parameter, all species-specific comparisons involving environmental and reproductive data were collected only during the run-time schedule that each taxon was historically in the upper river and not at other times (Figure 2B). In-river water temperature was obtained at the Department of Water Resources Lewiston Water Quality gauge (LWS; Figure 1), $1.7 \mathrm{rkm}$ downstream from the Lewiston Dam and hatchery (rkm 178.2; 40 43' 13N, 122 $47^{\prime \prime}$ 28W; elevation $558 \mathrm{~m}$ ). At the LWS gauge daily recordings of telemetered digital data were used to assess the seasonal extent of variability in the hydrology and thermal regime that characterized the upper Trinity River. Digital data included averaged daily: 1 ) maximum air temperature (ADAIR $\left.{ }^{\circ} \mathrm{C}\right), 2$ ) flow volume (ADFV $\left.\mathrm{m}^{3} / \mathrm{sec}\right)$, and 3 ) water temperature (ADWT $\left.{ }^{\circ} \mathrm{C}\right)$. Although punctuated up-and-down measurements using ADWT may approximate a bi-monthly framework for viewing this metric, it does not identify or illustrate extremes in daily water temperatures. Instead, the range (maximum - minimum) of extreme variability in daily water temperature (ADWTV ${ }^{\circ} \mathrm{C}$ ) was used to address the need for such a metric $[26,36]$. 
Data obtained from the LWS gauge was used for several specific reasons. 1) There are no other sources of flow augmentation from the watershed or major tributaries between the LWS gauge and hatchery. So, this section of the river is not inadvertently influenced by conditions attributable to the local watershed. 2) Water temperature in the hatchery is monitored daily from the main intake throughout the facility to the river effluent, which historically is assumed to be within $\sim 1^{\circ} \mathrm{C}$ (D. Muir, personal communication). Thus, the LWS gauge provides the most consistent and detailed longterm digital information reflecting water temperature used during each hatchery phase of fertilization, fertility estimation, egg production, juvenile grow-out, and release of hatcheryproduced anadromous salmonids. 3) Virtually all hatchery-raised Chinook Salmon spawn within the first $3.2 \mathrm{~km}$ below the Lewiston Dam, which consistently contains the largest densities of hatcheryorigin Chinook Salmon spawning redds [47]. 4) The LWS gauge is the closest gauge to the hatchery and provides the best location for measuring water temperature conditions for in-river spawning hatchery-origin Chinook Salmon and other anadromous species spawning in this segment of the reach. 5) The gauge provided data used in all National Environmental Protection Act (NEPA) assessments of flow augmentation and fluctuations in riverine average daily water temperature, specific to the upper Trinity River [35, 51].

\subsection{Timing and Measurement of Fertility at Hatchery}

Our analysis of hatchery-collected data included all years for which hard-counts of hatchery and "wild" stocks of adult fish (> $32 \mathrm{~cm}$ fork length) were available for spring- and fall-run Chinook Salmon (1994 - 2018), Coho Salmon (1990 - 2018), and steelhead (1990 - 2018; Table 1). This process was conducted in accordance with a Julian week (JW) schedule, defined as one of seven consecutiveday-sets of 52 weekly periods in a calendar year that allowed inter-annual comparisons of identical weekly periods. Brood-stock were collected by fyke trap at the hatchery during annual egg-take operations, which generally last for six months out of the year (JW36 [Labor Day in early September] - JW11 [17 March]; Table 1). Spring-run Chinook Salmon egg-take starts in early September and goes into mid-October (JW36 - JW41). A break in spawning of hatchery Chinook Salmon (spawning break) occurs in JW42 to segregate races. Fall-run Chinook Salmon egg-take starts in late October and lasts to early December (JW43 - JW50). Coho Salmon egg-take starts in early November and lasts to midDecember (JW45 - JW51). Steelhead egg-take consists of 12 consecutive Tuesdays beginning at the end of the year (JW52 - JW11).

Table 1 Species-specific seasonal schedule of egg-take at the hatchery during annual Julian week (JW) artificial spawning cycles, including the number of available speciesspecific years sampled for reproductive data. Measurements of all reproductive variables were obtained at the time of egg-take at the hatchery during the run-timing that each species was in the river.

\begin{tabular}{llllll}
\hline Species & Months & Julian weeks & Frequency & Spawn-days & Duration \\
\hline $\begin{array}{l}\text { Spring-run Chinook } \\
\text { Salmon (1994- 2018) }\end{array}$ & Sep-Oct & JW36-JW41 & twice per week & Monday, Thursday 5 weeks \\
$\begin{array}{l}\text { Fall-run Chinook Salmon } \\
(1994-2018)\end{array}$ & Oct - Dec & JW43-JW50 & twice per week & Monday, Thursday & 7 weeks \\
\hline
\end{tabular}




\begin{tabular}{llllll}
\hline $\begin{array}{l}\text { Coho Salmon (1990 - } \\
\text { 2018) }\end{array}$ & Nov - Dec & JW45 -JW51 & once per week & Tuesday & 6 weeks \\
Steelhead (1990-2018) & Dec - Mar & JW52-JW11 & once per week & Tuesday & 12 weeks \\
\hline
\end{tabular}

Measurements of reproductive variables were obtained for each species at the time of egg-take following a specific schedule (Table 1). Data were collected from fish that were ripe on the day of collection, including: 1) total number of eggs (ova) harvested at fertilization per spawn-day lot (TLEG) and 2) total number of eggs harvested that survived to the eyed ova stage or "final pick" (EAPIC). Dead eggs were removed daily, and each spawn-day lot was followed through to the final pick. Averaged daily percent fertility (ADPF) was calculated as: EAPIC / TLEG) * 100, which equates to percent of egg survival to the eyed ova stage for that spawn-day lot. Water was supplied to the hatchery from the base of Lewiston Dam. All developing ova were subject to ambient water temperatures that were within optimal species-specific thresholds. Traditional hatchery estimates of ADPF historically were used as an "index of fertility" derived from artificially propagated salmonids collected during the annual season when reproductively active adult cohorts of each species were in the upper Trinity River. Hatchery generated fertility estimates represent average spawn-day measurements based on the number of fish processed that spawn-day. The hatchery began supplementing the water in the spawning pans for fish eggs, with salt in the 2015 season, at a concentration of one cup per 0.24 liters of water. The salt solution was pre-mixed and added to each spawn-pan prior to sperm and eggs added. The intent was to reduce egg loss (i.e., improve fertility) in response to declining fertility in Chinook Salmon eggs brood-years 2012 to 2014 (personal communications L. Glenn [2014], and S. McCarn and S. Ballard [2015, 2017]). We found no documents indicating that this procedure was modified prior to 2014; thus, our regression models only consider annual trends in fertility through 2014 for each species.

\subsection{Statistical Analysis and Theoretical Distribution}

All analyses were performed used R [52] and statistical significance was set at $\alpha \leq 0.05$. Evaluation of univariate normality of temperature and flow volume measured the LWS gauge was assessed using the adjusted Anderson-Darling (AD.adj) statistic [53]. This analysis suggested that all environmental variables were not normally distributed ( $A D F V$ : $A D \cdot \operatorname{adj}=1,480, p<0.001, n=8,401$; ADWT: $A D \cdot a d j=8.7, p<0.001, n=8,055$; ADWTV: AD.adj = 276.1, $p<0.001, n=8,042$ ). Hatcheryderived species-specific reproductive attributes also deviated significantly from normality (TLEG: AD. adj $=73.8, p<0.001, n=1,435 ;$ EAPIC: AD.adj = 116.1, $p<0.001, n=1413 ;$ ADPF: AD.adj = 51.79, $p<0.001, n=1,187)$. Thus, all statistical analyses of both environmental and reproductive attributes used non-parametric methods [54]. Kruskal-Wallis Chi-square rank sum tests $\left(\chi^{2}\right)$ evaluated each variable among each designated flow-type group. When the omnibus test was rejected post-hoc planned pairwise comparisons between each group were made using the Dunn test statistic (Z). Pvalues were adjusted using the Benjamini-Hochberg method [55]. The Spearman rank correlation coefficient $\left(r_{s}\right)$ 2-tailed test calculated the strength and direction of the relationship between environmental and reproductive attributes [56]. Visual assessment of each environmental variable was conducted using two goodness-of-fit plots to determine the appropriate probability distribution (Figure S1; [57]). Q-Q plots and the Akaike information criterion goodness of fit statistic (AIC; [58]) suggested that a normal probability distribution more closely approximated ADWT. Whereas a Gamma probability distribution most closely approximated ADFV and ADWTV. Thus, the Gamma 
distribution was preferred in all subsequent regression analyses because it more correctly described the center and tails of the empirical distributions for each variable.

Semi-parametric Generalized Additive Models (GAM) were used in all regressions [59, 60]. Response curves generated from each GAM illustrate the relationship between the fitted function and the response variable. Statistics reported from each GAM were: 1) GAM-F (approximate significance of smooth terms) and p-value, 95\% confidence bands for spline lines [61], and adjusted regression coefficient ( $R^{2}$ adj.) for the model. The regression coefficient explained the degree to which each predictor variable(s) (ADWT and ADWTV) explained the greatest amount of variation in the predicted variable (ADPF). The Spearman's rank correlation coefficient was used to assess the strength and significance of each trend delineated by the smooth term [62]. Stationarity in each environmental variable (ADFV; ADWT; ADWTV) and estimate of fertility (ADPF) was evaluated in response to each species-specific flow-type hydrograph. Autocorrelation analyses of GAMgenerated residuals were used to investigate the relationship between each time point relative to each previous time point in the distribution of lag values for each metric.

This process facilitated a test of the hypothesis that flow-mediated thermal variance in river water could potentially affect estimates of fertility in co-occurring species in a similar way. The Augmented Dickey-Fuller (ADF) statistic, Box-Ljung test $\left(\chi^{2}\right)$, and Breusch-Godfrey test (LM; [63]) were used to evaluate stationarity, and test for low- and high-order serial correlation across lags, respectively. Generic k-fold cross validation was used to estimate the strength and ability of our models to predict future observations [64]. Several different metrics were used to measure the quality of each model. 1) A t-test measured the overall significance of the model. 2) $R^{2}$ measured the strength of the linear relationship between the predictor variable(s) and the response variable; where an $R^{2}=1.0$ indicates a perfect linear relationship, while an $R^{2}=0$ indicates no linear relationship. 3) Root Mean Squared Error (RMSE) measured the average prediction error made by the model in predicting the value for a new observation. 4) Mean Absolute Error (MAE) represents the average absolute difference between the true value of an observation and the value predicted by the model; it is generally less sensitive to outliers compared to RMSE. For both RMSE and MAE lower values indicate a better fit to the model.

\subsection{Ethics Statement}

Research presented here did not involve human, animal, or plant subjects, cell lines or clinical trials. All analyses were conducted with data previously collected at the hatchery or generated from physical parameters collected from the riverine environment.

\section{Results}

\subsection{Annual and Seasonal Trends in the Historical Time Series of Environmental Variables}

Significant overall differences in the historical annual trends of each flow-type hydrograph were observed for each environmental variable measured in-river at the LWS gauge (Table 2). For ADFV the baseline PreROD flow-type exhibited the greatest amount of variation relative to other flowtypes as measured by its standard deviation, which reflected a more climatically "natural" post-dam hydrograph compared to regularly manipulated managed hydrographs. For ADWT there was a distinct transition in the increased level of variance from PreROD and ROD to ROD + Pulse flows. All 
GAM regressions suggest that smooth terms for each environmental variable were non-linear and significant for each annual response curve, but the amount of variation explained by all regression coefficients was not robust ranging from $R^{2}$ adj. = 0.3\% (ADFV) to $R^{2}$ adj. $=17.8 \%$ (ADWTV; Figure $3 A, 3 B$, and $3 C$ ). Exaggerated variance in ADFV and ADWT was also evident in higher volumes of flow in years of ROD and ROD + Pulse flows. This pattern was particularly evident in extreme values of thermal variance (ADWTV). A clear distinction between ROD and ROD + Pulse flows on an annual basis was observed in 2017 for both ADWT and ADWTV (Figure 3B and 3C).

Table 2 Kruskal-Wallis Chi-square rank sum tests $\left(\chi^{2}\right)$ of each environmental variable measured at the Lewiston Water Quality (LWS) gauge for each managed flow-type hydrograph (PreROD, ROD, ROD + Pulse), followed by planned post-hoc Dunn tests (Z) of all pairwise comparisons. Measurements of all flow and water temperature data were obtained at the Lewiston Water Quality gauge during the run-timing that each species was in the river. Included were the arithmetic mean, lower (LCL) and upper (UCL) 95\% confidence limits, and the standard deviation (SD) for averaged daily: 1) flow volume $\left(\right.$ ADFV $\left.\mathrm{m}^{3} / \mathrm{sec}\right), 2$ ) water temperature (ADWT ${ }^{\circ} \mathrm{C}$ ), and 3) extreme variability in water temperature $\left(\mathrm{ADWTV}^{\circ} \mathrm{C}\right)$. Probability levels were calculated at: $<0.05=*,<0.01=* *$, $<0.001=* * *$.

\begin{tabular}{|c|c|c|c|c|c|c|c|}
\hline \multirow[b]{2}{*}{ Variable } & \multirow{2}{*}{\multicolumn{3}{|c|}{ Kruskal-Wallis / Dunn tests }} & \multicolumn{4}{|l|}{ Variable } \\
\hline & & & & Standard statistics & ADFV & ADWT & ADWTV \\
\hline ADFV & \multicolumn{3}{|c|}{$\chi^{2}=151.0, d f=2, p<0.001 * * *$} & \multicolumn{4}{|c|}{ PreROD $(n=2,190)$} \\
\hline Group(i) & Group $(j)$ & Z & $\mathrm{p}$-adj & Mean & 28.1 & 8.8 & 0.9 \\
\hline PreROD & ROD & 12.3 & $<0.001 * * *$ & $95 \% \mathrm{LCL}$ & 26.4 & 8.7 & 0.9 \\
\hline PreROD & ROD + Pulse & 7.7 & $<0.001^{* * *}$ & $95 \%$ UCL & 29.9 & 8.8 & 0.9 \\
\hline ROD & ROD + Pulse & 4.8 & $<0.001^{* * *}$ & SD & 40.5 & 1.1 & 0.5 \\
\hline ADWT & \multicolumn{3}{|c|}{$\chi^{2}=361.0, d f=2, p<0.001^{* * *}$} & \multicolumn{4}{|l|}{$\operatorname{ROD}(n=2,883)$} \\
\hline Group(i) & Group(j) & Z & $p-a d j$ & Mean & 26.9 & 8.9 & 0.9 \\
\hline PreROD & ROD & 4.4 & $<0.001 * * *$ & $95 \% \mathrm{LCL}$ & 25.5 & 8.8 & 0.9 \\
\hline PreROD & ROD + Pulse & 17.8 & $<0.001 * * *$ & $95 \%$ UCL & 28.3 & 8.9 & 0.9 \\
\hline ROD & ROD + Pulse & 14.4 & $<0.001 * * *$ & SD & 38.7 & 1.5 & 0.5 \\
\hline ADWTV & \multicolumn{3}{|c|}{$\chi^{2}=566.5, d f=2, p<0.001 * * *$} & \multicolumn{4}{|l|}{ Pulse $(n=2,745)$} \\
\hline Group(i) & Group(j) & Z & $p-a d j$ & Mean & 23.2 & 9.5 & 1.5 \\
\hline PreROD & ROD & 2.4 & $<0.001 * * *$ & $95 \% \mathrm{LCL}$ & 22.1 & 9.4 & 1.4 \\
\hline PreROD & ROD + Pulse & 21.0 & $<0.001 * * *$ & $95 \%$ UCL & 24.3 & 9.6 & 1.5 \\
\hline ROD & ROD + Pulse & 19.9 & $<0.001 * * *$ & SD & 28.2 & 1.7 & 1.0 \\
\hline
\end{tabular}



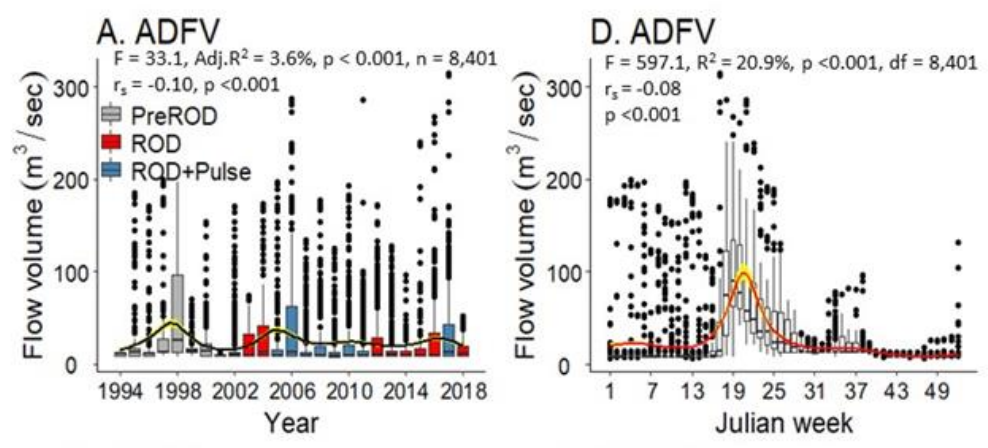

B. ADWT

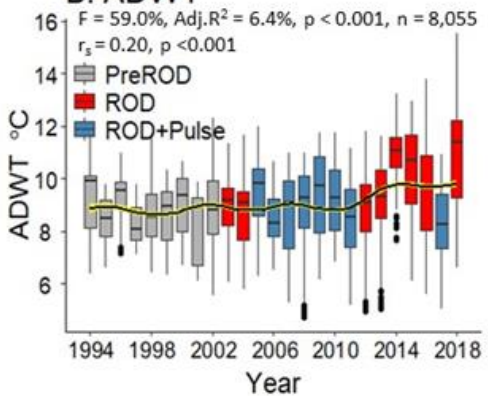

E. ADWT

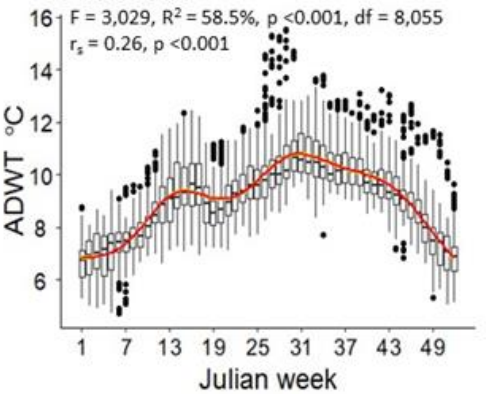

C. ADWTV
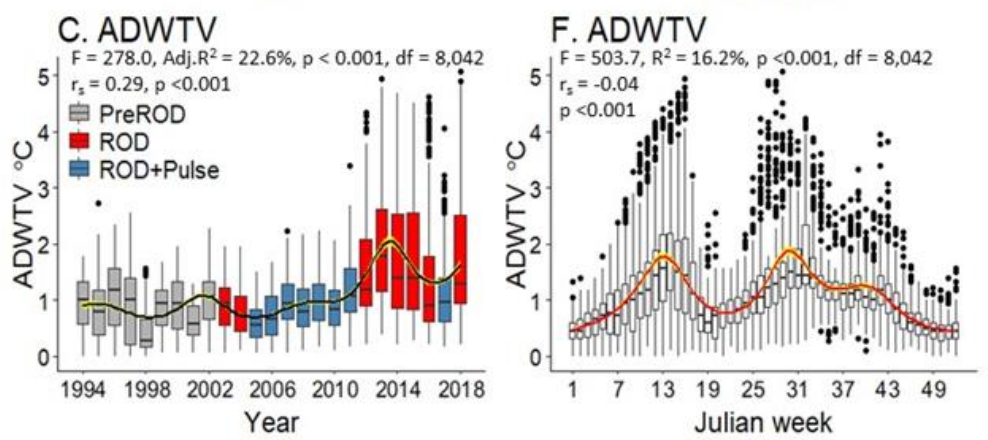

Figure 3 Composite boxplots of annual variation in average daily: A) flow volume (ADFV $\mathrm{m}^{3} / \mathrm{sec}$ ), B) water temperature (ADWT ${ }^{\circ} \mathrm{C}$ ), and C) extreme variability in water temperature (ADWTV ${ }^{\circ} \mathrm{C}$ ). Seasonal Julian week (JW) fluctuations are illustrated in: $\left.D\right)$ ADFV, E) ADWT, and F) ADWTV. Shaded smooths (colored yellow) indicate 95\% pointwise standard error for each curve surrounding each fitted Generalized Additive Model (GAM) function (centered black line) in A - B and centered red line in D - F). GAM regression statistics and Spearman rank correlation coefficients correspond to daily measurements of each variable from 1994 through 2019.

Here ROD flows resulted in lower values for both water temperatures variables (cooler and less variable) in conjunction with higher volumes of flow compared to ROD + Pulse flow years (2005 2011,2018 ) immediately preceding and after pulsed augmentation flows in 2018. This pattern is consistent with the seven consecutive ROD flows from 2005 to 2011. Ranked correlation analyses found significant positive relationships between year and both water temperature variables but the correlation between year and ADFV was negative. As expected, the correlation between ADWT and ADWTV was significant and positive $\left(r_{s}=0.52, p<0.001, n=8,042\right)$, but both water temperature variables were negatively correlated with ADFV $\left(r_{s}=-0.09, p=0.001, n=8,012\right.$ and $r_{s}=-0.27, p<$ $0.001, n=7,999$, respectively) and the strengths of the correlations were weak. Overall, patterns 
depicted by the regression and correlation analyses suggested that the historical water temperature in the upper-most reach below the hatchery tended to increase slightly on an annual basis, while the corresponding volume of flow tended to decline for the years sampled.

Similarly, the historical trends expressed in seasonal Julian week fluctuations in each environmental metric also exhibited non-linear patterns (Figure 3D, 3E, and 3F). Again, although all smooth terms were significant for each GAM response curve the relationship between the predictor (Julian week) and each environmental response variable was weak; with $\mathrm{R}^{2}$ adj. ranging from $58.5 \%$ (ADWT) to $16.2 \%$ (ADWTV). There was a significant positive relationship between Julian week and ADWT, but this relationship was negative for both ADFV and ADWTV. Although a seasonal component in the thermal regime extending from winter to fall was evident in ADWT, seasonal hydrographs describing ADFV were augmented by managed hydrographs. This pattern was reflected by extreme thermal variation in water temperature (ADWTV) as mirrored by the correlation with Julian week. Extrinsic to the thermal regime of flow volume we found that along this section of the upper mainstem the relationship between maximum air temperature (ADAIR) and both water temperature variables was positive and significant (ADWT: $r_{s}=0.672, p<0.001, n=5,664$ and ADWTV: $\left.r_{s}=0.48, p<0.001, n=5,664\right)$. The weak relationship between ADAIR and extreme thermal variance in water temperature, despite large sample size, may be a function of the nearness to the outlet at the base of Lewiston Dam in combination with the insulating effect of steep topography and narrowness of the adjacent canyon walls along this section of the river.

The extent of seasonal differentiation and dispersion among flow-types for each environmental variable was further evident when Julian week data were evaluated by flow-type (Figure 4). This process revealed seasonal irregularity in more traditionally cyclical fluctuations of each environmental variable for PreROD flows compared to: 1) high-volume ROD flow hydrographs employed systematically and continuously for in-river geomorphologic restoration (JW18 - JW22); and 2) ROD + Pulse flows intended for both in-river geomorphological work and secondarily to prompt upstream seasonal migration of Chinook Salmon out of the lower Klamath River to reduce the potential for density dependent disease transmission. Pulsed augmentations in conjunction with their companion ROD flow, and in odd years ceremonial flows (JW36 - JW40), accounted for more Julian weeks with extreme levels of thermal variance than either PreROD or individual ROD flows (Figure 4B, 4E, and 4H). This response was evident also by the saddle-shaped distribution of ADWTV on both sides of JW2O (Figure 4E[b], 4H[b], and 4I[b]), which was indicative of reduced thermal variability at the top of each annual hydrograph in volume of flow (Figure $4 \mathrm{~B}[\mathrm{~b}]$ relative to $4 \mathrm{H}[\mathrm{b}]$ ). The greatest amount of variability in water temperature was associated with both the ascending and descending slopes of peak discharge during ROD and ROD + Pulse flows. 

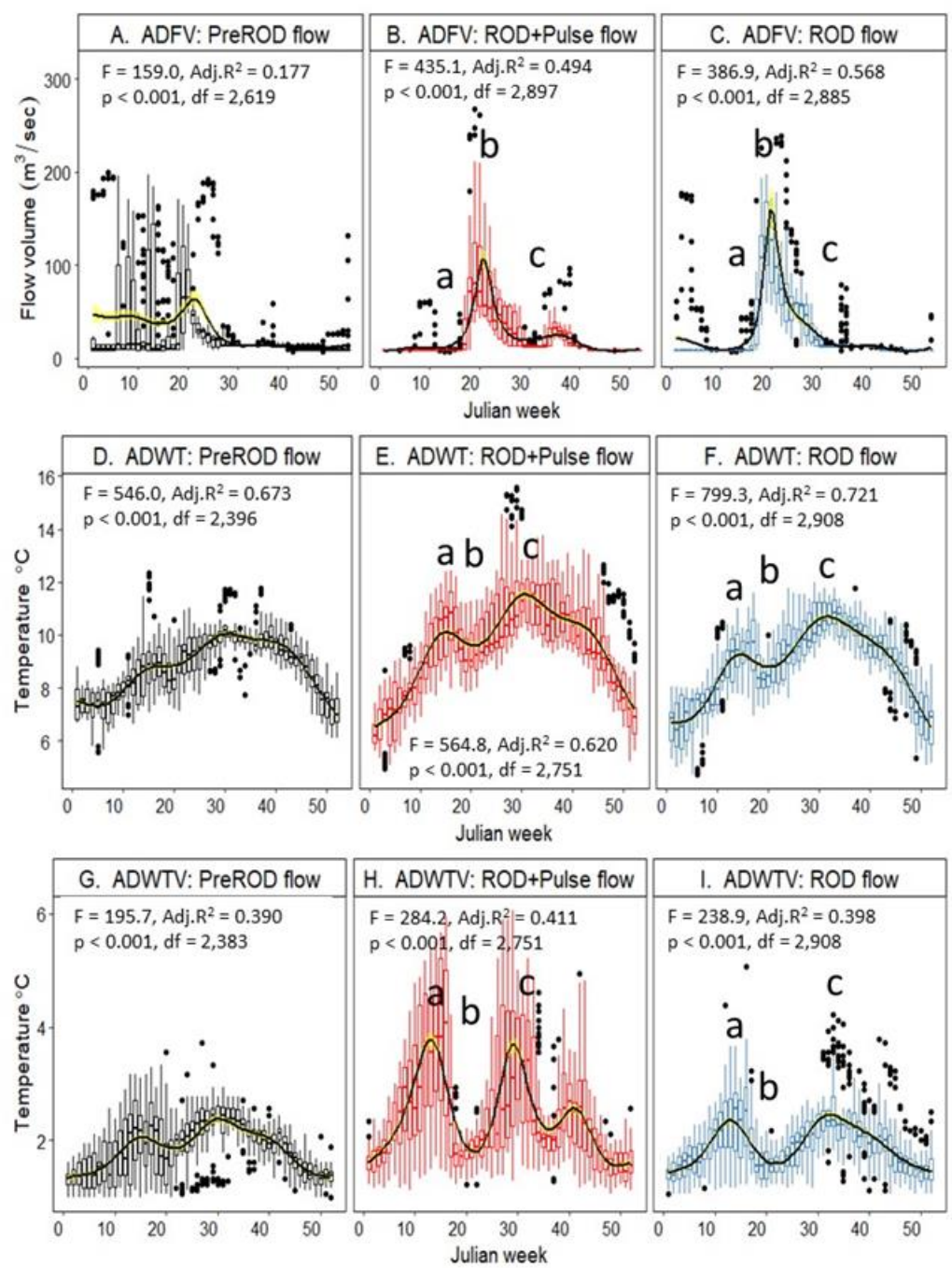

Figure 4 Flow-type boxplots of seasonal Julian week (JW) variation in average daily: flow volume (ADFV; $A-C$ ), water temperature (ADWT; D - F), and extreme variability in water temperature (ADWTV; $G$ - I). Lower case lettering reference subsections of each seasonal flow-type described in the text. Shaded smooth (colored yellow) indicate $95 \%$ point-wise standard error for each curve surrounding each fitted GAM function (centered black line); JW arranged sequentially beginning with JW01 (1 - 7 January) to JW52 (24 - 31 December). GAM regression statistics correspond to daily measurements of each variable from 1994 through 2019.

Importantly, the extreme flow-mediated water temperature fluctuations described above for each environmental variable resulting from managed hydrographs post-2002 were not characteristic of baseline PreROD flows. Similarly: 1) measurements obtained in-river at the LWS gauge indicated significant overall differences between flow-types for each environmental variable when evaluated in accordance with the historical run-time schedule of each species (Table 3); 2) planned post-hoc tests showed that $62.5 \%(n=48)$ of all pairwise comparisons were significantly different among flow-types for each species-specific environmental variable; and 3) the standard deviations for all environmental variables were consistently higher for ROD + Pulse flows and lowest for baseline PreROD flows in all species comparisons. 
Table 3 Kruskal-Wallis Chi-square rank sum tests $\left(\chi^{2}\right)$ of environmental variables measured at the Lewiston Water Quality gauge for each managed flow-type hydrograph (PreROD, ROD, ROD + Pulse) for each species of salmonid, followed by planned post-hoc Dunn test statistic (Z) of all pairwise comparisons. Measurements of all flow and water temperature data were obtained at the Lewiston Water Quality gauge during the run-timing that each species was in the river. P-values adjusted using Benjamini-Hochberg method. Included are the arithmetic mean, lower (LCL) and upper (UCL) 95\% confidence limits, and standard deviation (SD) for averaged daily: 1) flow volume (ADFV $\mathrm{m}^{3} / \mathrm{sec}$ ), 2) water temperature $\left(\mathrm{ADWT}^{\circ} \mathrm{C}\right)$, and 3 ) extreme variability in water temperature (ADWTV $\left.{ }^{\circ} \mathrm{C}\right)$. Probability levels: $<0.05=*,<0.01=* *,<$ $0.001=* * *$.

\begin{tabular}{|c|c|c|c|c|c|c|c|}
\hline \multirow{2}{*}{\multicolumn{8}{|c|}{$\begin{array}{l}\text { Species } \quad \text { Variable (Kruskal-Wallis / Dunn test) } \\
\text { Averaged dailv flow volume }\left(\mathrm{m}^{3} / \mathrm{sec}\right)\end{array}$}} \\
\hline & & \multicolumn{6}{|c|}{ Averaged daily flow volume $\left(\mathrm{m}^{3} / \mathrm{sec}\right)$} \\
\hline Spring-run Chinook Salmon & \multicolumn{3}{|c|}{ ADFV: $\chi^{2}=31.8, d f=2, p<0.001 * * *$} & Standard statistics & PreROD $(n=70)$ & $\operatorname{ROD}(n=88)$ & ROD + Pulse $(n=102)$ \\
\hline Group(i) & Group(j) & $\mathrm{Z}$ & $p$-adj & Mean & 14.07 & 13.05 & 20.6 \\
\hline PreROD & ROD & 1.3 & 0.106 & $95 \% \mathrm{LCL}$ & 12.72 & 12.99 & 17.98 \\
\hline PreROD & ROD + Pulse & 3.8 & $0.001 * * *$ & $95 \%$ UCL & 15.41 & 13.11 & 23.26 \\
\hline ROD & ROD + Pulse & 5.4 & $0.000 * * *$ & SD & 5.63 & 0.30 & 13.45 \\
\hline Fall-run Chinook Salmon & \multicolumn{3}{|c|}{ ADFV: $\chi^{2}=43.7, d f=2, p<0.001^{* * *}$} & Standard statistics & PreROD $(n=109)$ & $\operatorname{ROD}(n=134)$ & ROD + Pulse $(n=119)$ \\
\hline Group(i) & Group(j) & $\mathrm{Z}$ & p-adj & Mean & 9.79 & 8.61 & 8.6 \\
\hline PreROD & ROD & 6.3 & $0.000 * * *$ & $95 \% \mathrm{LCL}$ & 9.08 & 8.55 & 8.57 \\
\hline PreROD & ROD + Pulse & 5.0 & $0.000 * * *$ & 95. UCL & 10.49 & 8.67 & 8.71 \\
\hline ROD & ROD + Pulse & 1.2 & 0.116 & SD & 3.73 & 0.35 & 0.38 \\
\hline Coho Salmon & \multicolumn{3}{|c|}{ ADFV: $\chi^{2}=20.3, d f=2, p<0.001 * * *$} & Standard statistics & $\operatorname{PreROD}(n=59)$ & $\operatorname{ROD}(n=163)$ & ROD + Pulse $(n=105)$ \\
\hline Group(i) & Group(j) & Z & p-adj & Mean & 12.06 & 8.57 & 8.65 \\
\hline PreROD & ROD & 4.5 & $0.000 * * *$ & $95 \% \mathrm{LCL}$ & 8.60 & 8.57 & 8.58 \\
\hline PreROD & ROD + Pulse & 3.0 & $0.002 * *$ & $95 \%$ UCL & 15.52 & 8.68 & 8.73 \\
\hline ROD & ROD + Pulse & 1.6 & 0.058 & SD & 13.28 & 0.36 & 0.40 \\
\hline Steelhed & \multicolumn{3}{|c|}{ ADFV: $\chi^{2}=87.7, d f=2, p<0.001 * * *$} & Standard statistics & $\operatorname{PreROD}(n=88)$ & $\operatorname{ROD}(n=93)$ & ROD + Pulse $(n=63)$ \\
\hline Group(i) & Group(j) & $\mathrm{Z}$ & p-adj & Mean & 47.06 & 14.02 & 8.78 \\
\hline PreROD & ROD & 9.0 & $0.000 * * *$ & $95 \% \mathrm{LCL}$ & 34.26 & 9.31 & 8.72 \\
\hline PreROD & ROD + Pulse & 6.4 & $0.000 * * *$ & $95 \%$ UCL & 58.86 & 18.74 & 8.85 \\
\hline
\end{tabular}




\begin{tabular}{|c|c|c|c|c|c|c|c|}
\hline ROD & ROD + Pulse & 1.8 & $0.036 *$ & SD & 60.41 & 22.89 & 0.28 \\
\hline \multicolumn{8}{|c|}{ Average daily water temperature $\left({ }^{\circ} \mathrm{C}\right)$} \\
\hline Spring-run Chinook Salmon & \multicolumn{3}{|c|}{ ADWT: $\chi^{2}=55.4, d f=2, p<0.001 * * *$} & Standard statistics & PreROD $(n=70)$ & $\operatorname{ROD}(n=88)$ & ROD + Pulse $(n=102)$ \\
\hline Group(i) & Group $(j)$ & Z & p-adj & Mean & 9.69 & 9.86 & 10.58 \\
\hline PreROD & ROD & 3.1 & $0.001^{*}$ & $95 \% \mathrm{LCL}$ & 9.59 & 9.86 & 10.41 \\
\hline PreROD & ROD + Pulse & 7.3 & $0.000 * * *$ & $95 \%$ UCL & 9.79 & 10.12 & 10.75 \\
\hline ROD & ROD + Pulse & 4.4 & $0.000 * * *$ & SD & 0.42 & 0.60 & 0.86 \\
\hline Fall-run Chinook Salmon & \multicolumn{3}{|c|}{ ADWT: $\chi^{2}=12.2, \mathrm{df}=2, \mathrm{p}<0.002^{* *}$} & Standard statistics & PreROD ( $n=109)$ & $\operatorname{ROD}(\mathrm{n}=134)$ & ROD + Pulse $(n=109)$ \\
\hline Group(i) & Group(j) & Z & p-adj & Mean & 8.75 & 8.58 & 9.27 \\
\hline PreROD & ROD & 1.0 & 0.164 & $95 \% \mathrm{LCL}$ & 8.60 & 8.38 & 9.03 \\
\hline PreROD & ROD + Pulse & 2.4 & $0.014 * *$ & $95 \%$ UCL & 8.90 & 8.77 & 9.51 \\
\hline ROD & Pulse & 3.4 & $0.001 * * *$ & SD & 0.78 & 1.10 & 1.22 \\
\hline Coho Salmon & \multicolumn{3}{|c|}{ ADWT: $\chi^{2}=18.9, \mathrm{df}=2, \mathrm{p}<0.001^{* * *}$} & Standard statistics & PreROD $(n=59)$ & $\operatorname{ROD}(\mathrm{n}=163)$ & ROD + Pulse ( $n=105)$ \\
\hline Group(i) & Group(j) & Z & p-adj & Mean & 8.14 & 7.84 & 8.72 \\
\hline PreROD & ROD & 1.4 & 0.081 & $95 \% \mathrm{LCL}$ & 7.96 & 7.65 & 8.40 \\
\hline PreROD & ROD + Pulse & 2.2 & $0.031^{*}$ & $95 \%$ UCL & 8.32 & 8.02 & 9.03 \\
\hline ROD & ROD + Pulse & 4.4 & $0.000 * * *$ & SD & 0.69 & 1.20 & 1.61 \\
\hline Steelhed & \multicolumn{3}{|c|}{ ADWT: $\chi^{2}=18.7, d f=2, p<0.001^{* * *}$} & Standard statistics & PreROD $(n=88)$ & $\operatorname{ROD}(n=93)$ & ROD + Pulse $(n=62)$ \\
\hline Group(i) & Group(j) & $\mathrm{Z}$ & p-adj & Mean & 7.64 & 7.04 & 7.45 \\
\hline PreROD & ROD & 4.3 & $0.000 * * *$ & $95 \%$ LCL & 7.50 & 6.82 & 7.16 \\
\hline PreROD & ROD + Pulse & 1.6 & $0.050^{*}$ & $95 \%$ UCL & 7.77 & 7.26 & 7.73 \\
\hline ROD & ROD + Pulse & 2.2 & $0.019 *$ & $\mathrm{SD}$ & 0.64 & 1.08 & 1.12 \\
\hline \multicolumn{8}{|c|}{ Averaged daily extreme variation in water temperature $\left({ }^{\circ} \mathrm{C}\right)$} \\
\hline Spring-run Chinook Salmon & \multicolumn{3}{|c|}{ ADWTV: $\chi^{2}=14.8, \mathrm{df}=2, \mathrm{p}<0.001^{* * *}$} & Standard statistics & PreROD $(n=70)$ & $\operatorname{ROD}(n=88)$ & ROD + Pulse $(n=102)$ \\
\hline Group(i) & Group $(j)$ & Z & p-adj & Mean & 1.00 & 1.16 & 1.35 \\
\hline PreROD & ROD & 2.3 & $0.018^{*}$ & $95 \% \mathrm{LCL}$ & 0.95 & 1.07 & 1.23 \\
\hline PreROD & ROD + Pulse & 3.9 & $0.000 * * *$ & $95 \%$ UCL & 1.05 & 1.25 & 1.47 \\
\hline ROD & ROD + Pulse & 1.6 & $0.053^{*}$ & SD & 0.20 & 0.42 & 0.61 \\
\hline
\end{tabular}


Adv Environ Eng Res 2022; 3(1), doi:10.21926/aeer.2201009

\begin{tabular}{|c|c|c|c|c|c|c|c|}
\hline Fall-run Chinook Salmon & \multicolumn{3}{|c|}{ ADWTV: $\chi^{2}=14.0, \mathrm{df}=2, \mathrm{p}<0.001^{* * *}$} & Standard statistics & PreROD $(n=109)$ & $\operatorname{ROD}(n=134)$ & ROD + Pulse $(n=105)$ \\
\hline Group(i) & Group(j) & Z & p-adj & Mean & 0.55 & 0.70 & 0.80 \\
\hline PreROD & ROD & 2.3 & $0.014 * *$ & $95 \% \mathrm{LCL}$ & 0.50 & 0.62 & 0.71 \\
\hline PreROD & ROD + Pulse & 3.7 & $0.000 * * *$ & $95 \%$ UCL & 0.60 & 0.77 & 0.89 \\
\hline ROD & Pulse & 1.6 & 0.058 & SD & 0.26 & 0.43 & 0.46 \\
\hline Coho Salmon & \multicolumn{3}{|c|}{ ADWTV: $\chi^{2}=34.4, \mathrm{df}=2, \mathrm{p}<0.001^{* * *}$} & Standard statistics & PreROD $(n=59)$ & $\operatorname{ROD}(n=163)$ & ROD + Pulse $(n=105)$ \\
\hline Group(i) & Group(j) & Z & p-adj & Mean & 0.43 & 0.61 & 0.73 \\
\hline PreROD & ROD & 4.2 & $0.000 * * *$ & $95 \% \mathrm{LCL}$ & 0.38 & 0.56 & 0.67 \\
\hline PreROD & ROD + Pulse & 5.9 & $0.000 * * *$ & $95 \%$ UCL & 0.48 & 0.65 & 0.80 \\
\hline ROD & ROD + Pulse & 2.6 & $0.005^{* *}$ & $\mathrm{SD}$ & 0.19 & 0.27 & 0.36 \\
\hline Steelhed & \multicolumn{3}{|c|}{ ADWTV: $\chi^{2}=63.7, \mathrm{df}=2, \mathrm{p}<0.001^{* * *}$} & Standard statistics & PreROD $(n=88)$ & $\operatorname{ROD}(n=93)$ & ROD + Pulse $(n=62)$ \\
\hline Group(i) & Group(j) & Z & $\mathrm{p}$-adj & Mean & 0.52 & 0.77 & 1.27 \\
\hline PreROD & ROD & 3.6 & $0.000 * * *$ & $95 \% \mathrm{LCL}$ & 0.44 & 0.67 & 1.11 \\
\hline PreROD & ROD + Pulse & 8.0 & $0.000 * * *$ & $95 \%$ UCL & 0.60 & 0.87 & 1.44 \\
\hline ROD & ROD + Pulse & 4.8 & $0.000 * * *$ & SD & 0.37 & 0.49 & 0.65 \\
\hline
\end{tabular}




\subsection{Variation in Reproductive Attributes of Hatchery Parental Brood-Stock}

Annual hatchery production goals are set by the United States Bureau of Reclamation. To meet these goals the hatchery egg-take (TLEG) for spring-run Chinook Salmon was set at 3 million eggs, fall-run Chinook Salmon at 6 million eggs, Coho Salmon at 1.2 million eggs (reduced to 720,000 in 1990), and 2 million eggs for steelhead (reduced to 1,200,000 in 1990; Figure 5A - 5D). However, these goals: 1) have not been met since 2014 for spring-run Chinook Salmon; 2) only attained in 2018 since 2012 for Fall-run Chinook Salmon, 3) have not been met since 2015 for Coho salmon, and 4) have not been met since 2016 for steelhead. Alternatively, if EAPIC is used as an index the annual egg take of fertilized viable eggs for each species was much lower than for TLEG (Figure 5E $5 \mathrm{H})$. In contrast, TLEG harvested for Spring-run and fall-run Chinook and Coho salmon suggested negative trends for the same period $\left(r_{s}=-0.29, p=0.001, n=290 ; r_{s}=-0.15, p=0.004, n=392\right.$ and $r_{s}=-0.20, p=0.001, n=395$; respectively). Whereas the pattern in steelhead suggested a significant positive trend $\left(r_{s}=0.47, p=0.001, n=342\right)$. Except for steelhead averaged spawn-day trends in TLEG harvested for the years sampled reflected patterns consistent with sharp declines in stocks of all taxa since 2003 [45].

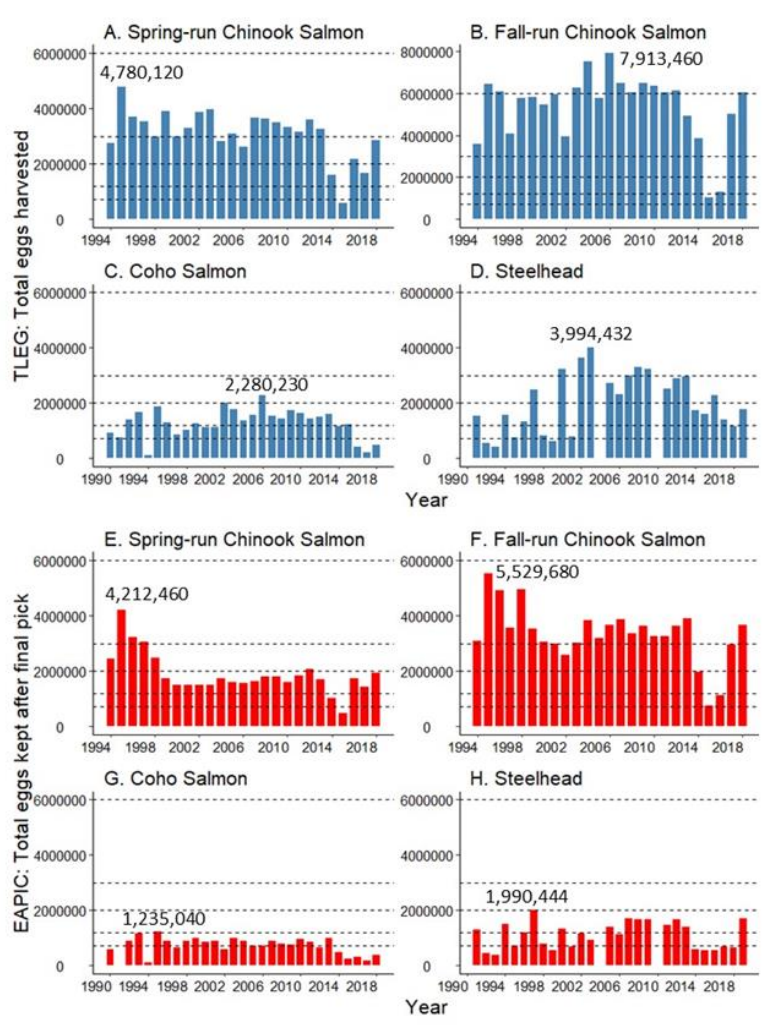

Figure 5 Bar graphs summarizing the total number of eggs harvested (TLEG; colored blue) and the total number of eggs left after the final pick (EAPIC colored red) by year from adult female salmonids spawned at the Trinity River Hatchery by species: springrun Chinook Salmon and fall-run Chinook Salmon (1994 - 2018), Coho Salmon (1990 2018), and steelhead (1990 - 2018). Years with maximum numbers of eggs harvested are indicated for both variables and dashed horizontal lines (colored black) correspond to species-specific egg-take goals discussed in the text. 
For all taxa except Coho Salmon there were significant overall differences in EAPIC (Table 4). Similarly, there were significant species-specific differences in $75.0 \%(n=12)$ of all planned in posthoc pairwise comparisons between flow-types. Except for Coho Salmon, the largest discrepancies between TLEG and EAPIC were observed in managed flow-types (Figure 6A - 6D); while the smallest discrepancies were found in baseline PreROD flows. These trends also were reflected by consistently higher variances (as measured by SD) in each species-specific flow-type for ROD and ROD + Pulse flow hydrographs compared to baseline PreROD flows. Accordingly, for Chinook Salmon and steelhead, irrespective of run-size and oversampling of eggs by the hatchery to meet mandated quotas, our results suggest that in years of managed hydrographs (to facilitate in-river restoration actions) there were significantly fewer viable eggs obtained at the hatchery compared to years of baseline Pre-ROD flows. Currently these subtle differences in estimates of fertility relative to flowtype are not being monitored. 
Table 4 Kruskal-Wallis Chi-square rank sum tests $\left(\chi^{2}\right)$ of the differences between total number of eggs collected and total number of eggs left after pick measured at the Trinity River Hatchery between flow-type hydrographs (PreROD, ROD, ROD + Pulse) for each species of salmonid, followed by planned post-hoc Dunn test statistic (Z) of all pairwise comparisons. Included are the arithmetic mean, lower (LCL) and upper (UCL) 95\% confidence limits, and standard deviation (SD). Probability levels: $<0.05=*,<0.01=* *,<0.001=* * *$.

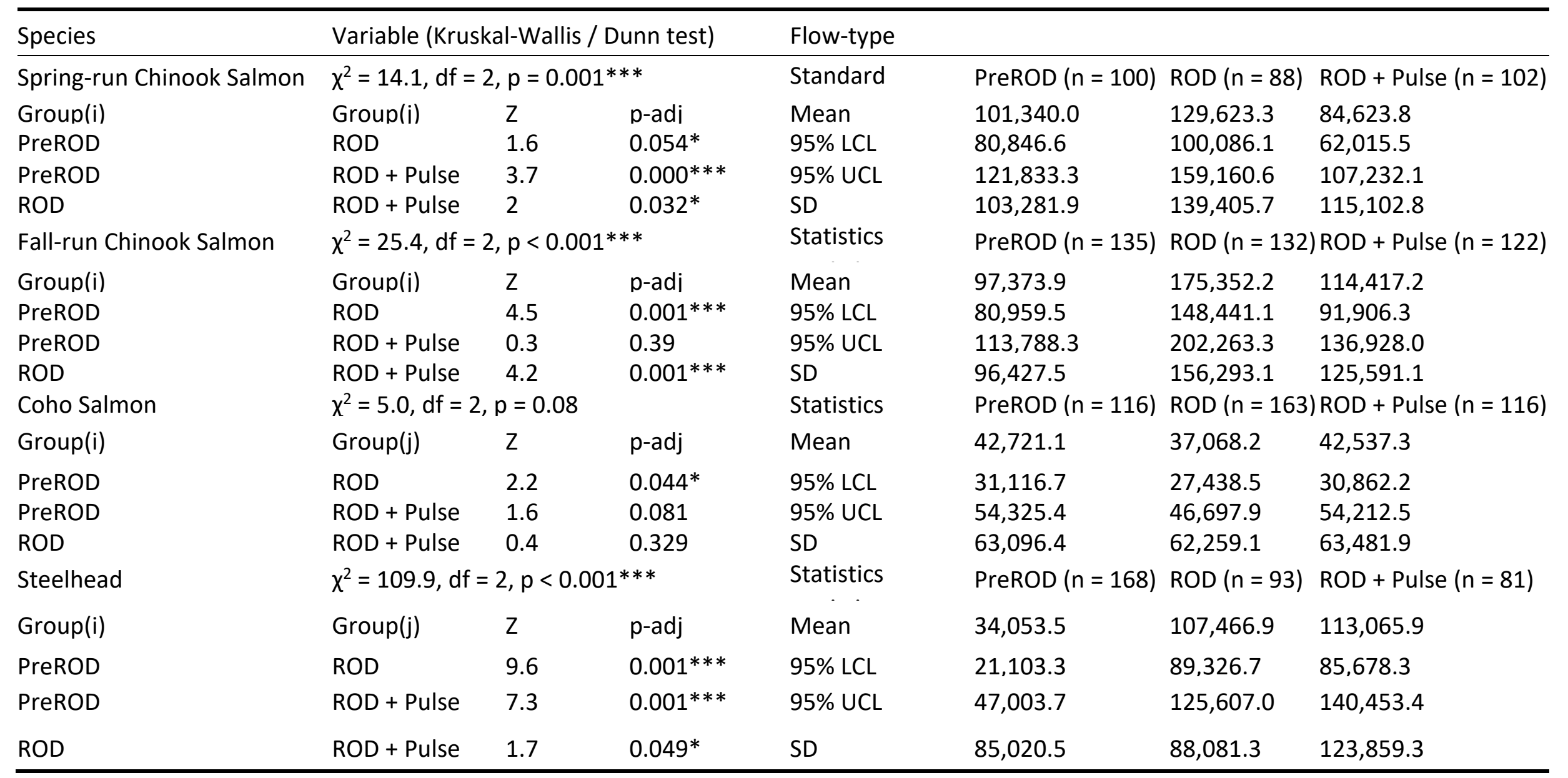



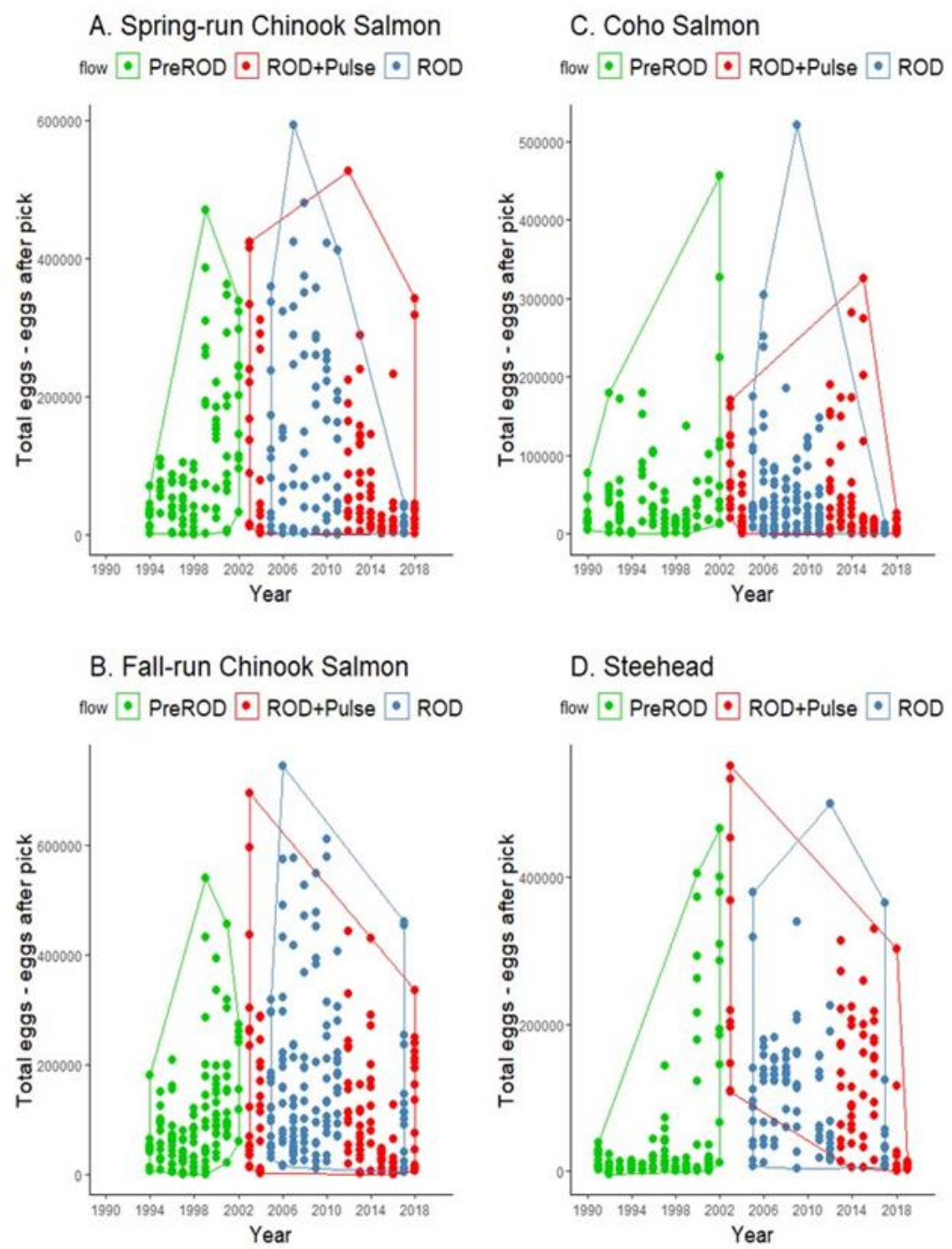

Figure 6 Polygons of species-specific flow-types illustrating the differences between the total number of eggs harvested (TLEG) and the total number of eggs left after the final pick (EAPIC) to remove dead eggs (TLEG - EAPIC).

\subsection{Autocorrelation in Species-Specific Annual Trends of Environmental Variables and Estimates Fertility}

Autocorrelation analyses of annual variation in both flow and water temperature variables and estimates of fertility by use of GAM residuals suggested virtual unanimity in stationarity. All lags were contained within approximate 95\% confidence limits for each variable in all species comparisons. All ADF-statistics were significant indicating stationarity in each comparison (Figure S2 and Figure S3). Both the Box-Ljung and Breusch-Godfrey tests indicated a lack of low- or highorder serial correlation among GAM residuals for all comparisons. Additionally, significant overall differences were observed in ADPF for all species-specific flow-types as indicated by Kruskal-Wallis Chi-square rank sum tests; and $83.3 \%(n=12)$ all post-hoc planed pairwise tests suggested significant differences between flow-types for each taxon (Table 5). Again, results indicated that for all species except fall-run Chinook Salmon, the greatest amount of dispersion (SD) in estimates of 
fertility were found in managed flows, especially in ROD + Pulse flow-years. Prior to the change in the methodology for estimating in fertility beginning in 2015, all salmonids artificially propagated at the hatchery experienced a significant annual decline in fertility through 2014 (Figure 7A - 7D). Post2014 estimates of fertility in all species except steelhead appeared to suggest an initial increase but in subsequent years appeared to decline through 2018. However, there are too few data to make a definitive statement about future trends in post-2014 estimates as methods for measuring fertility continue to be altered annually, which unfortunately prevents the possibility of developing a historical time series model that includes post-2014 estimates.

Table 5 Kruskal-Wallis Chi-square rank sum tests $\left(\chi^{2}\right)$ of the differences between species in averaged daily percent fertility (ADPF) estimated at the hatchery between flow-type hydrographs (PreROD, ROD, ROD + Pulse), followed by planned post-hoc Dunn test statistic (Z) of all pairwise comparisons. Included are the arithmetic mean, lower (LCL) and upper (UCL) 95\% confidence limits, and standard deviation (SD). Probability levels: $<0.05=*,<0.01=* *,<0.001=* * *$.

\begin{tabular}{|c|c|c|c|c|c|c|c|}
\hline \multirow{2}{*}{$\begin{array}{l}\text { Species } \\
\text { Spring-run } \\
\text { Chinook }\end{array}$} & \multicolumn{3}{|c|}{ Variable (Kruskal-Wallis / Dunn test) } & \multicolumn{4}{|c|}{ Flow-type } \\
\hline & \multicolumn{3}{|c|}{$\chi^{2}=47.1, d f=2, p<0.001^{* * *}$} & $\begin{array}{l}\text { Standard } \\
\text { statistics }\end{array}$ & $\begin{array}{l}\text { PreROD ( } \\
=100)\end{array}$ & $\operatorname{ROD}(n=73)$ & Pulse $(n=63)$ \\
\hline \multicolumn{8}{|l|}{ Salmon } \\
\hline Group(i) & Group(j) & Z & p-adj & Mean & 0.893 & 0.899 & 0.803 \\
\hline PreROD & ROD & 1.5 & 0.069 & $95 \%$ LCL & 0.884 & 0.882 & 0.773 \\
\hline PreROD & ROD + Pulse & 5.5 & $0.000 * * *$ & $95 \%$ UCL & 0.902 & 0.917 & 0.833 \\
\hline ROD & ROD + Pulse & 6.5 & $0.000 * * *$ & SD & 0.050 & 0.070 & 0.120 \\
\hline $\begin{array}{l}\text { Fall-run } \\
\text { Chinook }\end{array}$ & \multicolumn{3}{|c|}{$\chi^{2}=21.0, d f=2, p<0.001 * * *$} & $\begin{array}{l}\text { Standard } \\
\text { statistics }\end{array}$ & $\begin{array}{l}\text { PreROD (n } \\
=135)\end{array}$ & $\operatorname{ROD}(n=114)$ & Pulse $(n=77)$ \\
\hline \multicolumn{8}{|l|}{ Salmon } \\
\hline Group(i) & Group(j) & Z & p-adj & Mean & 0.850 & 0.882 & 0.800 \\
\hline PreROD & ROD & 2.6 & $0.008^{*}$ & $95 \%$ LCL & 0.831 & 0.868 & 0.773 \\
\hline PreROD & ROD + Pulse & 2.4 & $0.008^{*}$ & $95 \%$ UCL & 0.869 & 0.896 & 0.827 \\
\hline ROD & ROD + Pulse & 4.6 & $0.000 * * *$ & SD & 0.110 & 0.080 & 0.120 \\
\hline $\begin{array}{l}\text { Coho } \\
\text { Salmon }\end{array}$ & \multicolumn{3}{|c|}{$\chi^{2}=53.5, \mathrm{df}=2, \mathrm{p}<0.001 * * *$} & $\begin{array}{l}\text { Standard } \\
\text { statistics }\end{array}$ & $\begin{array}{l}\text { PreROD (n } \\
=169)\end{array}$ & $\operatorname{ROD}(n=146)$ & Pulse $(n=77)$ \\
\hline Group(i) & Group(j) & Z & $p$-adj & Mean & 0.790 & 0.670 & 0.640 \\
\hline PreROD & ROD & 6.6 & $0.000 * * *$ & $95 \%$ LCL & 0.770 & 0.640 & 0.590 \\
\hline PreROD & ROD + Pulse & 5.9 & $0.000 * * *$ & $95 \%$ UCL & 0.813 & 0.692 & 0.680 \\
\hline ROD & ROD + Pulse & 0.4 & 0.350 & SD & 0.120 & 0.160 & 0.200 \\
\hline Steelhead & \multicolumn{3}{|c|}{$\chi^{2}=132.7, d f=2, p<0.001^{* * *}$} & $\begin{array}{l}\text { Standard } \\
\text { statistics }\end{array}$ & $\begin{array}{l}\text { PreROD ( } \\
=169)\end{array}$ & $\operatorname{ROD}(n=83)$ & Pulse $(n=34)$ \\
\hline Group(i) & Group(j) & $\chi^{2}$ & $p$-adj & Mean & 0.880 & 0.610 & 0.820 \\
\hline PreROD & ROD & 11.5 & $0.000 * * *$ & $95 \% \mathrm{LCL}$ & 0.869 & 0.578 & 0.778 \\
\hline PreROD & ROD + Pulse & 2.6 & $0.005^{* *}$ & $95 \%$ UCL & 0.895 & 0.646 & 0.866 \\
\hline ROD & ROD + Pulse & 5.2 & $0.000 * * *$ & SD & 0.090 & 0.130 & 0.160 \\
\hline
\end{tabular}



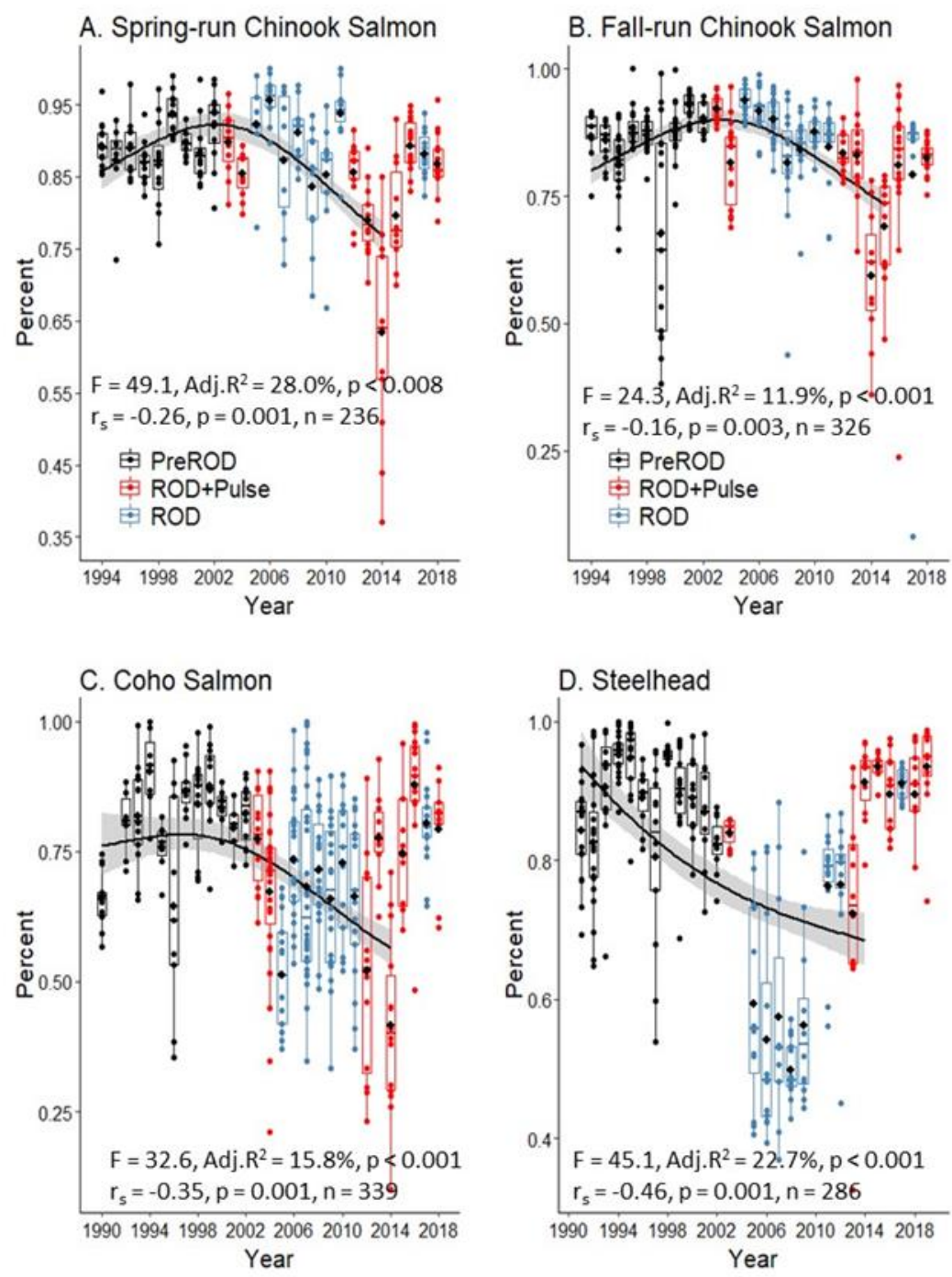

Figure 7 Generalized Additive Model (GAM) regression plots of annual fluctuations in averaged daily percent fertility (ADPF) association with species-specific flow-types. Shaded smooth (colored gray) areas indicate 95\% point-wise standard error distribution for each curve surrounding each fitted GAM function (centered black line). Annual hydrograph designations are indicated for baseline PreROD, ROD, and ROD + Pulse flows. GAM regression statistics and Spearman ranked correlation coefficients are for years 1994 to 2018 in both runs of Chinook Salmon and years 1990 to 2018 in each run of Coho Salmon and steelhead.

\subsection{Fertility as a Function of Water Temperature and Flow Volume}

Results of GAM regression showed a significant negative relationships between ADPF and both individual and combined water temperature variables (Table 6), and between flow-types for species-specific water temperatures (Table 3) measured in-river at the LWS gage for Chinook and Coho salmon, but not steelhead (Figure 8 and Figure 9). The negative relationship between ADPF and ADWT and between ADPF and ADWTV implies that as the temperature and thermal variability of river water increases estimates of fertility tends to decrease during species-specific run-time 
schedules. For example, in all polygon plots keyed to baseline PreROD flow, ADPF generally plotted above the regression line indicating relatively higher estimates of fertility in all species for this flowtype. Conversely, samples that identified managed flow-type hydrographs tended to plot below the regression line indicating relatively lower estimates of fertility for each species of salmonid. This was the situation whether the smoothed regression line was significant or not (ADWT for Coho Salmon and steelhead; Table 6). In all taxa this down-turn in the smoothed regression line for fertility typically occurred between $\sim 7.5^{\circ} \mathrm{C}$ and $\sim 9.0^{\circ} \mathrm{C}$ in ADWT in all species. The comparatively low end of the regression line in steelhead $\left(\sim 5.0^{\circ} \mathrm{C}\right)$ marked the beginning of the run-time spawning schedule in early spring in managed flow-type years (Figure 8D; Figure 2). A summary of speciesspecific cross-validation $R^{2}$ performance errors suggested a close match with results of the GAM $\left(R^{2}\right)$ regression models used to predict estimates of fertility (Table 6$)$. Except for $A D W T\left(R^{2}=35.8 \%\right.$ ) and ADWT + ADWTV $\left(R^{2}=34.8 \%\right)$ in spring-run Chinook Salmon the error variances explained were relatively low in each model for each species; whereas error measures for both MAE and RMSE were relatively high and similar across all cross-comparisons. However, the regression coefficient for both the GAM and cross-validation models decreased in parallel going from spring-run Chinook Salmon to steelhead, which corresponds to the timing at which each species is in the upper Trinity River and the sequential onset of annually managed flows. 
Table 6 Summary of species-specific Generalized Additive Modeling (GAM) and cross-validation model performance error measures for water temperature metrics (independent or predictor variables) versus average daily percent fertility (ADPF; dependent or response variable). $A D W T$ = averaged daily water temperature; $A D W T$ averaged daily extreme variability in water temperature; $\mathrm{R} 2=\mathrm{R}-\mathrm{squared}$; $\mathrm{RMSE}=$ root mean-square error; $\mathrm{MAE}=$ mean absolute error. Probability levels: $<0.05=*,<0.01=* *,<0.001=* * *$.

\begin{tabular}{|c|c|c|c|c|c|c|c|c|c|c|c|}
\hline \multirow[t]{2}{*}{ Species / predictor } & \multicolumn{4}{|l|}{ GAM regression } & \multicolumn{7}{|c|}{ Cross-validation summary } \\
\hline & F-value & Ref.df & $\mathrm{R} 2$ & $\mathrm{n}$ & $\mathrm{t}$-value & Std.error & Res.dev. & df & $\mathrm{R} 2$ & RMSE & MAE \\
\hline \multicolumn{12}{|c|}{ Spring-run Chinook Salmon } \\
\hline ADWT & $63.5^{* * *}$ & 2.0 & $38.3 \%$ & 206 & $9.6 * * *$ & 0.011 & 2.1 & 204 & $35.8 \%$ & 0.323 & 0.286 \\
\hline ADWTV & $5.1^{*}$ & 1.5 & $2.7 \%$ & & $2.5^{*}$ & 0.021 & 2.9 & 204 & $7.7 \%$ & 0.298 & 0.281 \\
\hline ADWT + ADWTV & $59.6 * * * * ; 1.2$ & $2.0 ; 1.9$ & $38.3 \%$ & & $9.2^{* * *} ; 0.1$ & $0.011 ; 0.192$ & 2.1 & 203 & $34.8 \%$ & 0.323 & 0.286 \\
\hline \multicolumn{12}{|c|}{ Fall-run Chinook Salmon } \\
\hline ADWT & $40.3 * * *$ & 2.0 & $17.2 \%$ & 297 & $6.0 * * *$ & 0.008 & 5.8 & 295 & $14.7 \%$ & 0.352 & 0.326 \\
\hline ADWTV & 2.7 & 1.0 & $0.7 \%$ & & 1.7 & 0.026 & 6.3 & 295 & $5.1 \%$ & 0.342 & 0.323 \\
\hline ADWT + ADWTV & $38.7^{* * *} ; 0.6$ & $2.0 ; 1.0$ & $17.2 \%$ & & $5.8^{* * *} ; 1.0$ & $0.008 ; 0.025$ & 5.8 & 294 & $13.1 \%$ & 0.352 & 0.327 \\
\hline \multicolumn{12}{|c|}{ Coho Salmon } \\
\hline ADWT & $42.6 * * *$ & 2.0 & $15.3 \%$ & 280 & $5.0 * * *$ & 0.017 & 21.6 & 278 & $12.2 \%$ & 0.814 & 0.781 \\
\hline ADWTV & $11.6^{* * *}$ & 1.7 & $7.0 \%$ & & $4.5^{* * *}$ & 0.077 & 21.8 & 278 & $9.6 \%$ & 0.812 & 0.780 \\
\hline \multicolumn{12}{|c|}{$4.7 * * *$} \\
\hline ADWT + ADWTV & $30.2^{* * *} ; 4.9 * *$ & $2.0 ; 1.5$ & $17.1 \%$ & & $4.2^{* * *}$ & $0.017 ; 0.075$ & 20.5 & 277 & $15.6 \%$ & 0.831 & 0.787 \\
\hline \multicolumn{12}{|c|}{ Steelhead } \\
\hline ADWT & $9.3 * * *$ & 1.8 & $5.7 \%$ & 198 & $3.5^{* * *}$ & 0.022 & 12.4 & 196 & $9.8 \%$ & 0.600 & 0.563 \\
\hline ADWTV & 0.2 & 1.3 & $0.3 \%$ & & 0.5 & 0.039 & 13.1 & 196 & $5.6 \%$ & 0.587 & 0.559 \\
\hline ADWT + ADWTV & $9.9 * * * ; 0.4$ & $1.7 ; 1.0$ & $5.3 \%$ & & $3.5^{* * *} ; 0.08$ & $0.023 ; 0.038$ & 12.4 & 195 & $8.6 \%$ & 0.601 & 0.563 \\
\hline
\end{tabular}



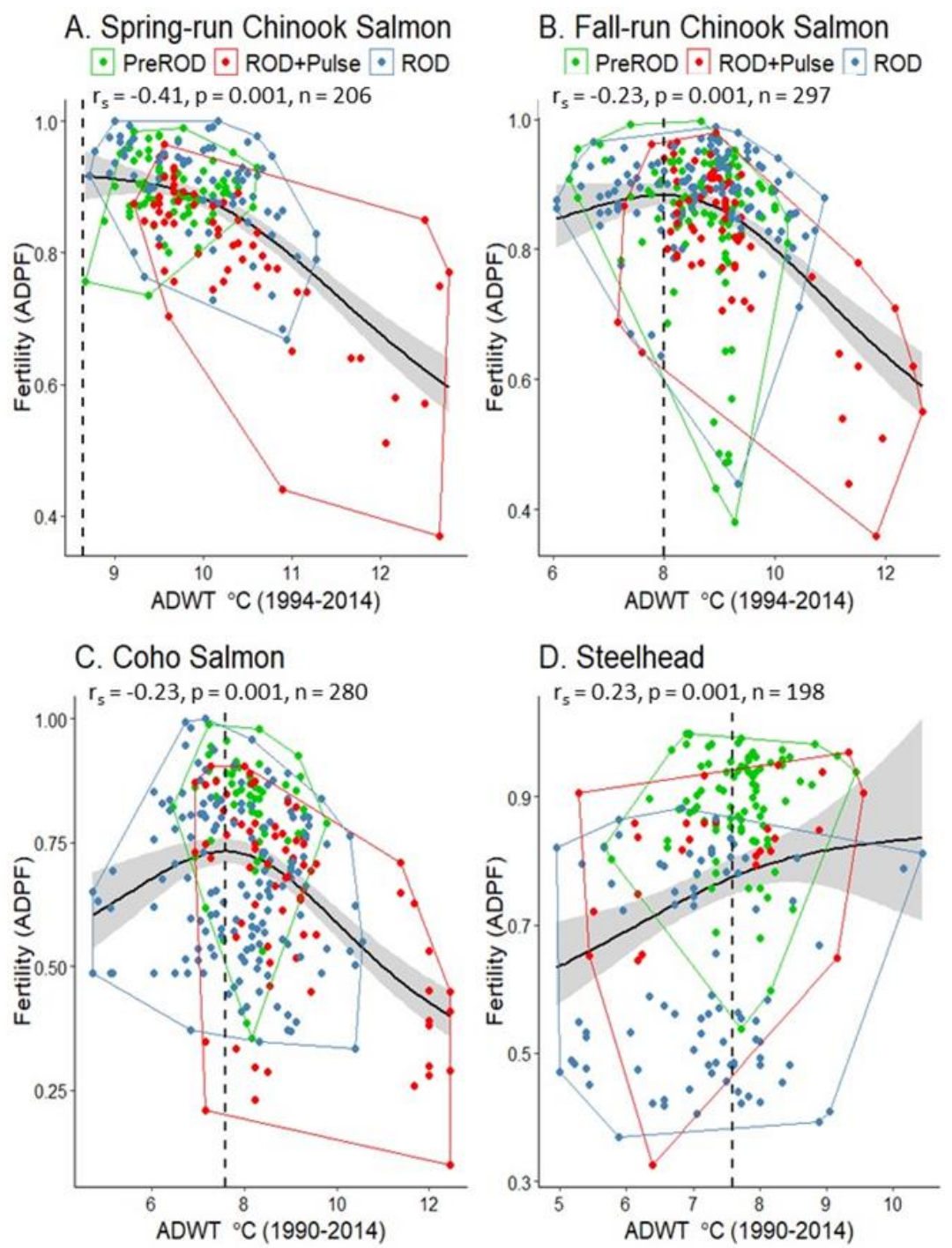

Figure 8 Polygons of species-specific fertility (ADPF) and Generalized Additive Model (GAM) regression plots showing the relationship between ADPF and average daily water temperature (ADWT) by flow-type. Shaded smooth (gray colored) areas indicate $95 \%$ point-wise standard error distribution for each curve surrounding each fitted GAM function (centered black line). Vertical dashed black lines indicate water temperature ranges between $\sim 7^{\circ} \mathrm{C}$ and $\sim 8^{\circ} \mathrm{C}$ for each comparison at which a measured decline in fertility first became noticeable. 

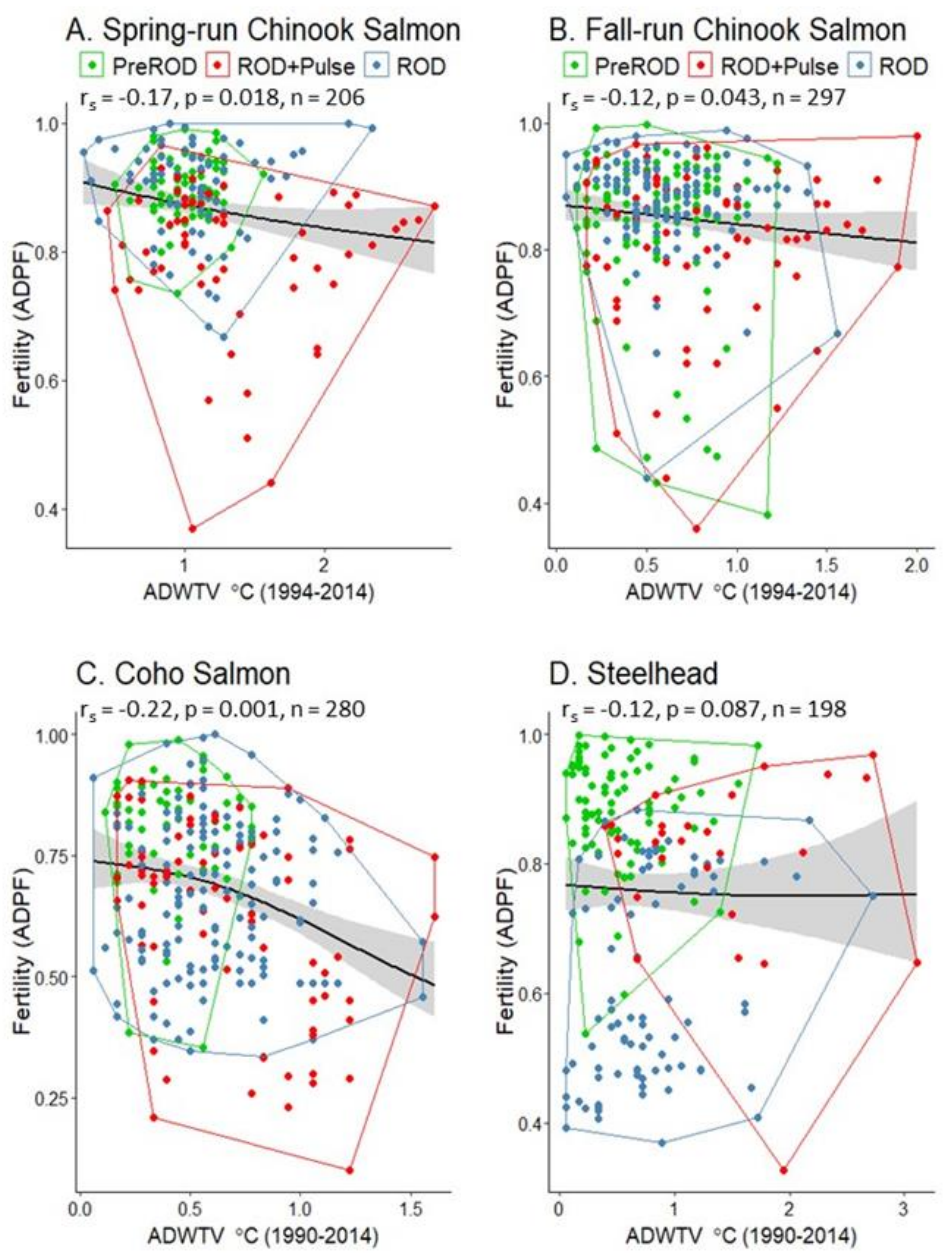

Figure 9 Polygons of species-specific fertility (ADPF) and Generalized Additive Model (GAM) regression plots showing the relationship between ADPF and extreme variability in average daily water temperature (ADWTV) by flow-type. Shaded smooth (gray colored) areas indicate $95 \%$ point-wise standard error distribution for each curve surrounding each fitted GAM function (centered black line).

\section{Discussion}

\subsection{Implications of Flow-Regulated Water Temperature}

Our study consists of several key findings. First, we found highly significant overall differences between flow-types in averaged daily flow volume, water temperature, and extreme variability in water temperature when evaluated in reference to the historical run-time schedule of each taxon. Second, we found significant differences among species-specific flow-types for each environmental variable. Third, we identified significant declines in the averaged daily number of total eggs harvested in all species except steelhead. Fourth, we provide evidence of significant overall differences in estimates of fertility for all species-specific flow-types, in which $83.3 \%$ of post-hoc planed pairwise comparisons revealed significant differences between flow-types for each taxon. Fifth, we observed significant annual declines in the historical estimates of fertility in all species through 2014 prior to a change in methodology for estimating fertility at the hatchery. That all 
species of spawned hatchery salmonids exhibited concordant declining trends in fertility suggests that taxa with divergent life history traits were responding to environmental conditions in parallel. When this measure of annual "fitness" drops in one species it also declined in all other sympatric taxa, whether in response to extrinsic events in the upper Trinity River or elsewhere. These negative species-specific annual trends in fertility were consistent with declining stocks observed in all species of anadromous salmonids that cohabitate the upper Trinity River [45]. Sixth, we documented significant negative correlations between species-specific estimates of fertility and both measures of water temperature in all taxa except steelhead. This may be that steelhead initiates spawning in late winter when the thermal regime is at its coldest before transitioning to warmer temperatures through the early fall spawning season. We suggest that a positive regression between fertility with increasing water temperature in steelhead is an expression of a diverse life history portfolio in which not all individuals are "genetically pre-programed to die" after spawning (semelparous) unlike salmon $[65,66]$. This evolved adaptation in steelhead may contribute to the species' resiliency and persistence despite anthropogenic effects and environmental variability potentially affecting growth and survival [67-71].

Our study focused on evaluating the statistical relationship between anthropogenically altered flow on hatchery-measured fertility as a proxy for use in modeling reproductive success in an assemblage of endemic salmonids. This process is necessary in identifying annual trends in reproductive performance among a multi-species assemblage of fish with different life history adaptations. We did not test for a "causal" interaction between flow-mediated water temperature and in-river estimates of fertility in spawning of hatchery- or natural-origin fish below Lewiston Dam, because these data are unknown. Similarly, the potential for flow-mediated thermal variance and its effects on fertility also remains unknown for fish spawning further downstream and in proximity to newly constructed restoration sites since 2003. However, it is reasonable to hypothesize that the cumulative effect of flow-mediated thermal variance on estimates of fertility in salmonids spawning in-river would be much more dramatic than what we have documented for hatchery fish. This is because of the greater thermal variance owing to fluctuations in flow volume, geomorphology, topography, and extrinsic climatic conditions found along this river system compared to more "controlled" and spatially confined hatchery conditions. Use of estimates of fertility in stocks of artificially spawned hatchery fish would appear to be a practicable baseline index for: 1) monitoring species-specific annual productivity and individual performance; and 2) providing a measure of relative "fitness" within a controlled hatchery environment for same-time contrasts with in-river hatchery and natural-area spawning fish.

We acknowledge that correlation and regression analyses do not necessarily equate to causation. Nevertheless, our results suggest that extreme variation in water temperature, as a function of highly managed flow regimes, has the potential to negatively affect fertility in several anadromous taxa with adaptively divergent life history adaptations. We suggest that concordance patterns among sympatric anadromous species are useful in providing initial insight and confidence into understanding the variance relationships in these metrics [72]. As with all correlative analyses there are noteworthy caveats: 1 ) fertility estimates used in our analysis were from hatchery escapement fish only and egg-take was determined by a process that was $100 \%$ artificial; and 2) although trends in fertility addressed herein may affect "wild" populations, similar empirical estimates of fertility in hatchery- and natural-origin spawning salmonids do not currently exist for the upper Trinity River. 
This is because in-river spawning has historically been monitored solely through indexing by annual surveys of carcass counts.

We note that cross-validation errors trended high across all species-specific comparisons, suggesting that our GAM models may be somewhat inefficient in their applicability to use future "out-of-sample testing" or unknown data [72, 73]. However, regression coefficients for both GAM and cross-validation models decreased in parallel going from spring-run Chinook Salmon to steelhead. Moreover, species-specific life-history strategies corresponded to the timing at which each taxon is in the upper Trinity River and the onset of annually managed flows. We hypothesize that model relevance and efficiency would be improved if in-river estimates of fertility and thermal variance were used during the run-time spawning schedules in which reproductively "ripe" fish were actually in the upper river. Importantly, both GAM regression and cross-validation models identified declines in estimates of fertility in relationship to water temperature going from spring-run to fallrun Chinook Salmon, Coho Salmon, and to steelhead. This pattern is plausible given that: 1) springrun Chinook Salmon are more exposed to managed flow regimes on an annual basis than any other anadromous species because their presence in the upper river coincides with the onset of ROD and ROD + Pulse hydrographs, which are function of annual long-term geomorphological restoration actions in combination with pulsed flow events; and 2 ) the sequence and timing of spawning is such that fall-run Chinook Salmon, Coho Salmon and steelhead occur in ordered succession progressively later in the year when annual ambient water temperatures naturally drop.

\subsection{Flow, Temperature, and Other Co-Variates}

Our study sought to identify a regional explanation for declining fertility in stocks of co-occurring salmonids in the upper Trinity River. As such, we focused on the relationship between water temperature and anthropogenic altered volumes of flow. Yet other co-variates not yet studied in both salt and fresh water may also affect annual and seasonal patterns of relative abundance, timing of migration, and estimates of fertility in spawning salmonids. Some of these co-variants include genetics, nutrition in the marine life history stage, and water quality in the freshwater upstream migration life history stage. A current narrative is that returning adult Chinook in the Trinity River, as well as other stocks along the west coast, exhibit clinical signs of thiamine deficiency in the last two spawn cohorts $[74,75]$. Similarly, ocean conditions are frequently cited as the primary cause for decreasing stocks of anadromous salmonids in the Pacific Northwest as a function of food availability in both adult and juvenile fish in association with regional drought. However, yet to be fully documented are the linkages and the extent to which regional drought, thiamine deficiency, degraded watersheds, or conditions in the ocean individually or cumulatively pose direct threats to inland fisheries [38, 40, 76-78]. To be useful, information on these and other potentially pertinent co-variates must be known, available, reliably sampled, and consistently gathered throughout a defined sampling period. Such requirements are critical in time series modeling, model evaluation, and forecasting. Yet these data are not currently available for the Trinity River and most all other riverine systems. What we do known is that anthropogenic flow manipulation does influence the behavior of pre-spawn fish during migration if fish migrate too fast or too early $[45,46]$. For Chinook Salmon, the effects of flow on fish also impose severe logistical constraints for management of hatchery operations and compliance with established mandates, which potentially affect estimates of fertility by narrowed ripening curves and delaying gametic maturation. What is lacking is a 
comprehensive assessment of the effects of managed flows on the condition of pre-spawn fish in route to the hatchery and in the traditional spawning grounds downstream during species-specific run-time scheduling.

We also acknowledge that the potential effects of annually managed flows on thermal variance of the mainstem Trinity River occurs predominantly before spawning, except in early spring-run and early arriving fall-run Chinook Salmon [45]. This does not mean, however, that subsequent development to juveniles is unaffected by managed flows if extreme thermal variability is a potential factor affecting in-river spawning [Table S1]. For example, extreme fluctuations in water temperature, as a function of managed hydrology, coincide with the in-river run timing and the duration of life history events for all four taxa (i.e., ontogeny of fry emergence, juvenile rearing, and juvenile and smolt out-migration) in the Trinity River. These events are diagrammatically outlined in the life history schedule for each species in the Trinity River Flow Evaluation Final Report, which was written prior to initiation restoration actions [49]. Yet evaluation of the relationships between flow-mediated water temperature and the potential effects on estimates of fertility, behavior, or other life history attributes have not been the focus of in-river: 1) spawning and production assessments in relation to potential flow-fish-effects, 2) geomorphological restoration actions relative to baseline "control" conditions, or 3 ) investigations into other co-variates that also could affect fitness.

Pre-ROD flows pre-date ( 60 years) post-dam construction and restoration. As such, pre-ROD flows are perhaps more similar to what endemic species of salmonids evolved with because high flow events more closely tracked weather conditions and pre-dam hydrographs. Collectively, our results suggest that these differentiated species are tracking thermal conditions in the upper Trinity River in parallel. This pattern may in part be a function of managed hydrologic events post-2003, which deviate dramatically from variability associated with the new "post-dam norm" [36]. Importantly, pre-restoration flows and thermal regimes that have characterized seasonal hydrographs in concert with regionally unimpeded tributary flow events automatically factor in annual variability in climate change. Given the continuation of emerging evidence of direct and indirect effects of thermal variance of river water on salmon fertility, growth, development, and susceptibility of salmonid eggs to in-river survival and altered emergence timing $[25,77,79]$, it seems prudent that resource managers prioritize consideration of the potential effects of fluctuating thermal variance associated with anthropocentric flow manipulation in highly regulated rivers. This approach is particularly critical in relation to: 1 ) the distribution, abundance and habitat attributes of salmonid redds, 2) successful egg incubation and follow-on development to fry emergence, 3) outmigrant survival, and 4) quality of newly created juvenile rearing habitat as a function of altered floodplain geomorphology. The latter of which may adversely impact speciesspecific scheduling of regionally adapted behavioral life history strategies by resident taxa. Nevertheless, there are also other more proximate factors that influence the biology of resident salmonids at the regional and local levels. Increasingly, the lack of knowledge resulting from integrated, well-designed, and long-term restoration programs that have weak or questionable validity, is in large measure the basis of considerable criticism by the scientific community that river restoration actions are poorly designed and fail too often [80-84]. 


\subsection{Management Considerations}

Scientific and policy communities acknowledge the need for maintaining or restoring natural flow variability to sustain the ecological health of fluvial ecosystems given the growing evidence of the potential negative consequences of altered flow regimes on these systems and the fisheries they support [26]. Understanding the potential effects of altered flow regimes on fisheries productivity and the linkage to extreme fluctuations in the thermal regime facilitates avoidance of uncertainties when assessing flow-fish productivity to enable adaptive management [19, 24]. Because alterations in the variance of riverine thermal regimes occur in response to anthropogenic events, these issues may inevitably become more problematic as climate change predictably progresses in-step with the demand for water [10, 25, 85-87]. In the mainstem Trinity River numerous reports have addressed fluctuations in water temperature, but only in the context of average daily water temperature [35, $52,88,89]$. This was the metric used to determine potential direct, indirect, and cumulative effects to the affected environment associated with late summer pulse flow that were supplemental to the ROD flow from Lewiston Dam in 2015 and 2016 [90]. Yet there has been no attempt to equate, measure, or monitor the potential effects of thermal variance on estimates of in-river fertility or reproductive output in anadromous salmonids associated with altered flow regimes initiated in 2003. Such an effort is crucial as late summer pulse flows temporally occur during the upstream migratory phase of the lifecycle of adult salmonids. Thus, contrary to the statement by Zedonis [91], the effects of augmented flow management on Trinity River stage and thermal variance are not well known, particularly as relates to a post-dam construction baseline time series model [36], potential effects on the ecology of the river system, and the life history adaptations of co-occurring anadromous salmonids.

Given the results and limitations of our study, we suggest that a more refined and long-term research focus is needed. Such a re-examination would allow simultaneous annual comparisons of fertility rates and egg-to-outmigrant survival at both the hatchery and in-river cohorts of the spawning population. The potential for thermal variance in river water, as a function of flow management, to effect biological and ecological processes suggests that more emphasis should be placed on collection, analysis, monitoring, and archiving variability in long-term flow and water temperature data. As noted by Zillig et al. [24] "Simple static temperature criteria can be improved by incorporating local data on salmonid fundamental physiology and on ecological conditions to produce population-specific thermal management strategies." We believe this suggestion also applies in a coordinated way to both hatchery operations and simultaneously down river at multiple locations within traditional natural area spawning sites. Examination of the effects of thermal variance, seasonality, and heterogeneity at multiple time scales seems more appropriate than simply applying a mean value to monthly, weekly, or daily variation in water temperature and flow volume. A study design of this kind has been demonstrated successfully for Chinook Salmon within the Chiwawa River, Washington [92]. This recommendation strongly relates to valuation of in-river fertility, production in salmonid populations, and the need to address declining stocks of salmonids in conjunction with hatchery operations and restoration of the mainstem Trinity River [86].

As such, we offer the following recommendations. 1) Compile historical data that relate ecological responses to variation in flow and water temperature consistent with seasonal run-time schedules of focal species at the hatchery and simultaneously in-river to compare with measures of species-specific fitness and habitat quality [92-94]. 2) Initiate Science-based experiments to 
determine empirical responses by salmonids in response to timing and volume of flow, and thermal variance. 3) Use the un-inhibited headwaters above Trinity Reservoir and major tributaries of the Trinity River to model and gauge ecological response to flow. 4) Modify existing spawning surveys to evaluate redd and carcass data for specific geo-rectified spawning criteria $[95,96]$ in order to better understand the underlying mechanisms of ecological response to flow in both the mainstem and major tributaries of the Trinity River. This approach has been used in assessing salmonid habitat suitability below Lewiston Dam [97] and juvenile rearing habitat at channel rehabilitation sites along the Trinity River [98]. 5) Monitor and model variation in the thermal regime at the hatchery from egg-take to juvenile outmigration in conjunction with same day collection of air and water temperatures, and flow data within traditional spawning grounds immediately below the inflow into the Trinity River from Lewiston Dam, and selected sites downstream within the mainstem corridor. 6) Annually randomly sample and monitor via regression analyses the relationship between forklength (i.e., size distribution) and reproductive metrics (number of eggs, size, estimates of fertility) in representative subsamples of individual/age cohort species-specific hatchery spawners. 7) Evaluate habitat quality at the location of each carcass and redd occupied by live un-marked females that do not fit the category of "hatchery spawning" fish based on proximity to the hatchery [47]; and assess the reproductive condition of female whole carcasses that link biological data to habitat data gathered at each site.

\section{Acknowledgments}

We thank several anonymous reviewers for their helpful editorial comments, suggestions, and numerous probing questions, which in several instances will require future research despite our best efforts to address them.

\section{Author Contributions}

Robert Sullivan developed the concept, analyzed and modeled the data, developed the graphics, and wrote the manuscript. John Hileman provided the initial raw data, knowledge and discussion about hatchery operations and fish biology in general, and edited portions of the manuscript.

\section{Funding}

Funding was not provided for this research effort.

\section{Competing Interests}

The authors declare that no competing interests exist.

\section{Additional Materials}

The following additional materials are uploaded at the page of this paper.

1. Table S1: Examples of phenology, life stage, and life history characteristics affected by thermal variance in water temperature or flow volume referenced to citation and outcome. 
2. Table S2: Water-year volume and flow-type summaries for managed hydrographs used for inriver restoration (ROD and ROD + Pulse flows) for Trinity River releases and diversions to the Central Valley of California since 2003. Modified from the Trinity River Restoration (TRRP 2021) webpage, which provides explanations as to how water volume metrics were calculated (https://www.trrp.net/restoration/flows/summary); ac-ft = acre feet; cfs = cubic feet per second in accordance with the webpage.

3. Figure S1: Goodness-of-fit plots for normal and Gamma variable distributions fitted to measures of averaged daily: A) flow volume (ADFV m3/sec). B) water temperature (ADWT ${ }^{\circ} \mathrm{C}$ ), and C) extreme variability in water temperature (ADWTV ${ }^{\circ} \mathrm{C}$ ). Plots include theoretical density (colored blue) and quantile-quantile ( $Q-Q)$ plots (colored red).

4. Figure S2: Plots showing time series autocorrelation analyses of environmental variables measured at the Lewiston Water Quality gauge for each species during the time that they were in the upper river. Analyses used residuals derived from Generalized Linear Models (GAM): A - C) spring-run Chinook Salmon (SRC), D - F) fall-run Chinook Salmon (FRC), G - I) Coho Salmon (COS), and $\mathrm{J}-\mathrm{L}$ ) steelhead (STL). Environmental variables were average daily: flow volume (ADFV $\mathrm{m} 3 / \mathrm{sec}$ ), water temperature (ADWT ${ }^{\circ} \mathrm{C}$ ), and extreme variability in water temperature (ADWTV ${ }^{\circ} \mathrm{C}$ ). Augmented Dickey-Fuller test $=\mathrm{ADF}$, Box-Ljung test $=\chi 2$, and Breusch-Godfrey test $=\mathrm{LM}$. Horizontal axis shows different lag values, vertical axis shows the autocorrelation at each lag value, and $95 \%$ confidence limits (bands) for the ACF function correlogram (blue dashed horizontal lines).

5. Figure S3: Plots of the results of time series autocorrelation (ACF) analyses of averaged annual percent fertility (ADPF) obtained from fish spawned at the hatchery at the time that they were inriver. Analyses use residuals derived from Generalized Linear Models (GAM) for each species: A) spring-run Chinook Salmon (SRC), B) fall-run Chinook Salmon (FRC), C) Coho Salmon (COS), and D) steelhead (STH). The Augmented Dickey-Fuller test $=$ ADF, Box-Ljung test $=\chi 2$, and Breusch-Godfrey test $=$ LM. The horizontal axis shows different lag values, and the vertical axis shows the autocorrelation at each lag value. Also included are 95\% confidence limits (bands) for the ACF function correlogram (blue dashed horizontal lines).

\section{References}

1. Smialek N, Pander J, Geist J. Environmental threats and conservation implications for Atlantic salmon and brown trout during their critical freshwater phases of spawning, egg development and juvenile emergence. Fish Manag Ecol. 2021; 28: 437-467.

2. Ward JV, Stanford JA. Ecological factors controlling stream zoobenthos with emphasis on thermal modification of regulated streams. In: Ecology of regulated streams. Boston: Springer; 1979. pp.35-55.

3. Geist J. Editorial: Green or red: Challenges for fish and freshwater biodiversity conservation related to hydropower. Aquat Conserv. 2021; 31: 1551-1558.

4. Hallock RJ, Elwell RF, Fry DH. Migrations of adult king salmon, Oncorhynchus tshawytscha, in the San Joaquin Delta, as demonstrated by use of sonic tags. California: Department of Fish and Game; 1970.

5. Elliott JM. Some aspects of thermal stress on freshwater teleosts. In: Stress and fish. London: Academic Press; 1981. pp.209-245. 
6. McCullough DA. A review and synthesis of effects of alterations to the water temperature regime on freshwater life stages of salmonids, with special reference to Chinook salmon [Internet]. Washington: United States Environmental Protection Agency; 1999. Available from: https://scholarworks.umass.edu/fishpassage reports/425/.

7. Carter JL, Resh VH, Rosenberg DN, Reynoldson TB. Biomonitoring in North American rivers: A comparison of methods used for benthic macroinvertebrates in Canada and the United States. In: Biological monitoring of rivers: Applications and perspectives. New York, NY: John Wiley and Sons Ltd; 2006. pp.203-228.

8. Olden JD, Naiman RJ. Incorporating thermal regimes into environmental flows assessments: Modifying dam operations to restore freshwater ecosystem integrity. Freshw Biol. 2010; 55: 86-107.

9. Myrick CA, Cech JJ. Temperature effects on juvenile anadromous salmonids in California's central valley: What don't we know? Rev Fish Bio Fish. 2004; 14: 113-123.

10. Crozier LG, Hendry AP, Lawson PW, Quinn TP, Mantua NJ, Battin J, et al. Potential responses to climate change for organisms with complex life histories: Evolution and plasticity in Pacific salmon. Evol Appl. 2008; 1: 252-270.

11. Crozier $L$, Siegel J. Impacts of climate change on salmon of the Pacific Northwest. Washington: NOAA; 2017.

12. Sinokrot BA, Gulliver SJ. In-stream flow impact on river water temperatures. J Hydraul Res. 2000; 38: 339-349.

13. Carter $\mathrm{K}$. The effects of temperature on steelhead trout, coho salmon, and Chinook salmon biology and function by life stage: Implications for Klamath Basin TMDLs. Santa Rosa, CA: North Coast Regional Water Quality Control Board; 2005.

14. Weinheimer J, Anderson JH, Downen M, Zimmerman M, Johnson T. Monitoring climate impacts: Survival and migration timing of summer chum salmon in Salmon Creek, Washington. Trans Am Fish Soc. 2017; 146: 983-995.

15. Beckman BR, Gadberry B, Parkins P, Larsen DA. The effect of Yakima River spring Chinook salmon sire life-history type on emergence timing and size of progeny. Trans Am Fish Soc. 2008; 137: 1285-1291.

16. Lytle DA, Poff NL. Adaptation to natural flow regimes. Trends Ecol Evol. 2004; 19: 94-100.

17. Konrad CP, Olden JD, Lytle DA, Melis TS, Schmidt JC, Bray EN, et al. Large-scale flow experiments for managing river systems. BioScience. 2011; 61: 948-959.

18. Mims MC, Olden JD. Fish assemblages respond to altered flow regimes via ecological filtering of life-history strategies. Freshw Bio. 2013; 58: 50-62.

19. Rytwinski T, Taylor JJ, Bennett JR, Smokorowski KE, Cooke SJ. What are the impacts of flow regime changes on fish productivity in temperate regions? A systematic map protocols. Environ Evid. 2017; 6: 1-7.

20. Spence BC, Lomicky GA, Hughes RM, Novitzki RP. An ecosystem approach to salmonid conservation. Corvallis: ManTech Environmental Research Services Corporation; 1996.

21. Magnuson JJ, Crowder LB, Medvick PA. Temperature as an ecological resource. Am Zool. 1979; 19: 331-343.

22. Pool GC, Berman $\mathrm{CH}$. An ecological perspective on in-stream temperature: Natural heat dynamics and mechanisms of human-caused thermal degradation. Environ Manag. 2001; 27: 787-802. 
23. Dunham J, Schroeter R, Rieman B. Influence of maximum water temperature on occurrence of Lahontan cutthroat trout within streams. North Am J Fish Manag. 2003; 23: 1041-1049.

24. Zillig KW, Lusardi RA, Moyle PB, Fangue NA. One size does not fit all: Variation in thermal ecophysiology among Pacific salmonids. Rev Fish Biol Fish. 2021; 31: 95-114.

25. Steel E, Tillotson AA, Larsen DA, Fullerton AH, Denton KP, Beckman BR. Beyond the mean: The role of variability in predicting ecological effects of stream temperature on salmon. Ecosphere. 2012; 3: 1-11.

26. Vasseur DA, DeLong JP, Gilbert B, Greig HS, Harley CD, McCann KS, et al. Increased temperature variation poses a greater risk to species than climate warming. Proc Royal Soc B. 2014; 281: 20132612.

27. Steel EA, Beechie TJ, Torgersen CE, Fullerton AH. Envisioning, quantifying, and managing thermal regimes on river networks. BioScience. 2017; 67: 506-522.

28. Cooper SD, Barmuta L, Sarnelle O, Kratz K, Diehl S. Quantifying spatial heterogeneity in streams. J North Am Benthol Soc. 1997; 16: 174-188.

29. Wehrly K, Wiley MJ, Seelbach PW. Classifying regional variation in thermal regime based on stream fish community patterns. Trans Am Fish Soc. 2003; 132: 18-38.

30. Rosenberg DB, Freedman SM. Temporal heterogeneity and ecological community structure. Int J Environ Stud. 1994; 46: 97-102.

31. McGrath EO, Neumann NN, Nicholet CF. A statistical model for managing water temperature in streams with anthropogenic influences. River Res Appl. 2017; 33: 123-134.

32. Arscott DB, Tockner K, Ward JV. Thermal heterogeneity along a braided floodplain river (Tagliamento River, northeastern Italy). Can J Fish Aquat Sci. 2001; 58: 2359-2373.

33. Webb BW, Noblis F. Long term water temperature trends in Austrian rivers. Hydrol Sci J. 1995; 40: 83-96.

34. Schär C, Vidale PL, Lüthi D, Frei C, Häberli C, Liniger MA, et al. The role of increasing temperature variability in European summer heatwaves. Nature. 2004; 427: 332-336.

35. Scheiff $T$, Zedonis $P$. The influence of Lewiston Dam releases on water temperatures of the Trinity and Klamath Rivers, CA April to October 2011. Arcata, CA: U.S. Fish and Wildlife Service, Arcata Fish and Wildlife Office; 2012; DS 2012-24.

36. Sullivan RM, Hileman JP. Time series modeling and forecasting of a highly regulated riverine system: Implications for fisheries management. Calif Fish Wildl. 2020; 106: 221-259.

37. Sommer TR, Harrell WC, Feyrer F. Large-bodied fish migration and residency in a flood basin of the Sacramento River, California. Ecol Freshw Fish. 2014; 23: 414-423.

38. Mann ME, Gleick PH. Climate change and California drought in the 21st century. PNAS. 2015; 112: 3858-3859.

39. Grozier L. Impacts of climate change on salmon of the Pacific northwest. Washington DC: Fish Ecology Division, Northwest Fisheries Science Center, National Marine Fisheries Service, NOAA; 2015.

40. Adams PB, Ainley D, Nelson P. Impacts of El Niño on adult Chinook salmon (Oncorhynchus tshawytscha) weight in the Gulf of the Farallones from 1983 to 2015. Calif Fish Game. 2017; 103: 177-182.

41. Romberger CZ, Gwozdz S. Performance of water temperature management on the Klamath and Trinity Rivers, 2017. Arcata, CA: Arcata Fisheries Data Series DS; 2018; 59.

42. Caissie D. The thermal regime of rivers: A review. Freshw Bio. 2006; 51: 1389-1406. 
43. TRRP. Trinity river restoration program [Internet]. Weaverville, CA: TRRP; 2022. Available from: http://www.trrp.net.

44. Sullivan RM, Hileman JP. Annual and seasonal variation, relative abundance, and effects of managed flows on timing of migration in Brown Trout (Salmo trutta) in the upper Trinity River. Calif Fish Game. 2018; 104: 99-128.

45. Sullivan RM, Hileman JP. Effects of managed flows on Chinook salmon in relation to run-timing, average annual percent fertility, and fluctuations in water temperature and flow volume. Calif Fish Game. 2019; 105: 132-176.

46. Sullivan RM, Hileman JP. Comparative analyses of upstream migration in a multispecies assemblage of fish in response to highly managed flow regimes. Calif Fish Game. 2020; 106: 99138.

47. Rupert DL, Gough SA, Som NA, Davids NJ, Matilton BC, Hill AM, et al. Mainstem Trinity River Chinook salmon spawning survey, 2015 and 2016. Arcata, CA: U.S. Fish and Wildlife Service; 2017; DS 2017-56.

48. Leith H. Phenology and seasonality modeling. New York: Springer. 1974.

49. U.S. Fish, Wildlife Service, Hoopa Valley Tribe. Trinity River flow evaluation. Arcata, CA and Hoopa, CA: U.S. Fish and Wildlife Service Hoopa Valley Tribe to the Secretary; 1999.

50. U.S. Department of the Interior. Record of decision: Trinity River mainstem fishery restoration: Final environmental impact statement/environmental impact report. Washington, DC: U.S. Department of the Interior; 2000.

51. Magneson MD, Chamberlain CD. The influence of Lewiston Dam releases on water temperatures of the Trinity River and lower Klamath River, CA, April to October 2014. Arcata, CA: U. S. Fish and Wildlife Service; 2015; 41.

52. Computing RF. R: A language and environment for statistical computing. Vienna: R Core Team; 2013.

53. Razali NM, Wah YB. Power comparisons of Shapiro-Wilk, Kolmogorov-Smirnov, Lilliefors, and Anderson-Darling tests. J Stat Model Anal. 2011; 2: 21-33.

54. McDonald JH. Handbook of biological statistics. 3rd ed. Baltimore, MD: Sparky House Publishing; 2014.

55. Benjamini $\mathrm{Y}$, Hochberg Y. On the adaptive control of the false discovery rate in multiple testing with independent statistics. J Educ Behav Stat. 2000; 25: 60-83.

56. Corder GW, Foreman DI. Nonparametric statistics: A step-by-step approach. Hoboken, NJ: John Wiley and Sons; 2014.

57. Cullen AC, Frey HC. Probabilistic techniques in exposure assessment: A handbook for dealing with variability and uncertainty in models and inputs. New York: Plenum Publishing Corporation; 1999.

58. Akaike H. Information theory and an extension of the maximum likelihood principle. In: 2nd international symposium on Information Theory. Budapest: Akademiai Kiado; 1973. pp.267281.

59. Hastie T, Tibshirani R. Generalized additive models. New York: Routledge; 1990.

60. Madsen H, Thyregod P. Introduction to general and generalized linear models. Boca Raton, FL: CRC Press; 2011.

61. Nychka D. Bayesian confidence intervals for smoothing splines. J Am Stat Assoc. 1988; 83: 11341143. 
62. Diankha O, Thiaw M. Studying the ten years variability of octopus vulgaris in Senegalese waters using generalized additive model (GAM). Int J Fish Aquat Stud. 2016; 4: 61-67.

63. Godfrey LG. Testing against general autoregressive and moving average error models when the regressors include lagged dependent variables. Econometrica. 1978; 46: 1293-1301.

64. Kuhn M, Wing J, Weston SA, Williams A, Keefer C, Engelhardt A, et al. Caret: Classification and regression training [Internet]. CRAN; 2016. Available from:

https://mran.microsoft.com/snapshot/2016-08-07/web/packages/caret/index.html.

65. Hall J, Roni P, Bennett T, McMillan J, Hanson K, Moss R, et al. Life-history diversity of steelhead in two coastal Washington watersheds. Trans Am Fish Soc. 2016; 145: 990-1005.

66. Dobos ME, Bowersox BJ, Copeland T, Stark EJ. Understanding life-history diversity of a wild steelhead population and managing for resiliency. N Am J Fish Manag. 2020; 40: 1087-1099.

67. Quinn TP. The behavior and ecology of Pacific salmon and trout. Seattle, WA: University of Washington Press; 2005.

68. Narum SR, Zendt JS, Graves D, Sharp WR. Influence of landscape on resident and anadromous life-history types of Oncorhynchus mykiss. Can J Fish Aquac Sci. 2008; 65: 1013-1023.

69. Moore JW, Yeakel JD, Peard D, Lough J, Beere M. Life-history diversity and its importance to population stability and persistence of a migratory fish: Steelhead in two large North American watersheds. J Anim Eco. 2014; 83: 1035-1046.

70. Ohms HA, Sloat MR, Reeves GH, Dunham JB. Influence of sex, migration distance, and latitude on life-history expression in steelhead and Rainbow Trout (Oncorhynchus mykiss). Can J Fish Aquac Sci. 2014; 71: 70-80.

71. Bourret SL, Caudill CC, Keefer ML. Diversity of juvenile Chinook salmon life-history pathways. Rev Fish Bio Fish. 2016; 26: 375-403.

72. Anderson SH, Gatzwiller KJ. Habitat evaluation methods. In: Research and management techniques for wildlife and habitats. Bethesda, MD: Wildlife Society; 1996. pp.592-606.

73. Stone M. Cross-validatory choice and assessment of statistical predictions. J R Stat Soc Series B Stat Methodol. 1974; 36: 111-133.

74. Lindley S, Cranford A. NMFS SWFSC Report: Thiamine deficiency in west coast salmon. 2021. Available from: https://www.pcouncil.org/documents/2021/02/e-1-attachment-1-thiaminedeficiency-in-west-coast-salmon.pdf/.

75. Rust S. Something was killing baby salmon; scientists traced it to a food-web mystery [Internet]. City of Los Angeles: Los Angeles Times; 2021. Available from:

https://www.latimes.com/environment/story/2021-01-26/king-salmon-vitamin-deficiencysacramento-river/.

76. Dettinger M, Cayan DR. Drought and the California Delta-a matter of extremes. San Francisco Estuary Watershed Sci. 2014: 12. doi: 10.15447/sfews.2014v12iss2art4.

77. Diffenbaugh NS, Swain DL, Touma D. Anthropogenic warming has increased drought risk in California. PNAS. 2015; 112: 3931-3936.

78. Michel CJ, Ammann AJ, Lindley ST, Sandstrom PT, Chapman ED, Thomas MJ, et al. Chinook salmon outmigration survival in wet and dry years in California's Sacramento River. Can J Fish Aquac Sci. 2015; 72: 1749-1759.

79. Martin BT, Dudley PN, Kashef NS, Stafford DM, Reeder WJ, Tonina D, et al. The biophysical basis of thermal tolerance in fish eggs. Proc Royal Soc B. 2020; 287: 20201550. 
80. Palmer MA, Menninger HL, Bernhardt E. River restoration, habitat heterogeneity and biodiversity: A failure of theory or practice? Freshw Biol. 2010; 55: 205-222.

81. Feld CK, Birk S, Bradley DC, Hering DH, Kail J, Marzin A, et al. Chapter three - from natural to degraded rivers and back again: A rest of restoration ecology theory and practice. Adv Ecol Res. 2011; 44: 119-209.

82. Pasternack GB. Geomorphologist's guide to participating in river rehabilitation. In: Treatise on geomorphology, vol 9, fluvial geomorphology. Oxford: Academic; 2013.

83. Morandia B, Piégaya H, Lamouroux N, Vaudora L. How is success or failure in river restoration projects evaluated? Feedback from French restoration projects. J Environ Manage. 2014; 137: 178-188.

84. Pasternack GB. River restoration: Disappointing, nascent, yet desperately needed. Earth Syst Environ Sci. 2020. doi: 10.1016/B978-0-12-409548-9.12449-2.

85. Tockner K, Pusch M, Borchardt D, Lorang MS. Multiple stressors in coupled river-floodplain ecosystems. Freshw Biol. 2010; 55: 135-151.

86. McCullough DA, Bartholow JM, Jager HI, Beschta RL, Cheslak EF, Deas ML, et al. Research in thermal biology: Burning questions for cold-water stream fishes. Rev Fish Sci. 2009; 17: 90-115.

87. Munsch SH, Greene CM, Johnson RC, Satterthwaite WH, Imaki H, Brandes PL. Warm, dry winters truncate timing and size distribution of seaward-migrating salmon across a large, regulated watershed. Ecol Appl. 2019; 29: e01880.

88. Magneson MD. The influence of Lewiston Dam releases on water temperatures of the Trinity River and lower Klamath River, CA, April to October 2012. Arcata, CA: U.S. Fish and Wildlife Service; 2013; DS 2013-30.

89. United States Bureau of Reclamation (USBR). Environmental assessment. Lower Klamath River late-summer flow augmentation from Lewiston Dam. Washington, DC: United States Bureau of Reclamation; 2015.

90. United States Bureau of Reclamation (USBR). Environmental assessment 2016 lower Klamath River flow augmentation from Lewiston Dam. Washington, DC: United States Bureau of Reclamation; 2016.

91. Zedonis PA. Empirical and theoretical influences of a pulse flow from Lewiston Dam on water temperature and dissolved oxygen of the lower Klamath River. Arcata, CA: U.S. Fish and Wildlife Service; 2001.

92. Hughes MS, Murdoch AR. Spawning habitat of hatchery spring Chinook salmon and possible mechanisms contributing to lower reproductive success. Trans Am Fish Soc. 2017; 146: 10161027.

93. Bisson PA, Montgomery DR. Valley segments, stream reaches, and channel units. In: Methods in stream ecology. San Diego, CA: Academic Press; 1969.

94. Arend KK. Macrohabitat identification. In: Aquatic habitat assessment: Common methods. Bethesda: American Fisheries Society. 1999.

95. Rosenfeld JS. Developing flow-ecology relationships: Implications of nonlinear biological responses for water management. Freshw Biol. 2017; 62: 1305-1324.

96. Kuhn J, Casas-Mulet R, Pander J, Geist J. Assessing stream thermal heterogeneity and coldwater patches from UAV-based imagery: A matter of classification methods and metrics. Remote Sens. 2021; 13: 1379. 
97. Hampton M, Payne TR, Thomas JA. Microhabitat suitability criteria for anadromous salmonids of the Trinity River. Arcata, CA: U.S. Fish and Wildlife Service; 1997; 15.

98. Goodman DH, Martin AM, Alvarez J, Davis A, Polos J. Assessing Trinity River salmonid habitat at channel rehabilitation sites, 2007-2008. Arcata, CA: U.S. Fish and Wildlife Service; 2010.

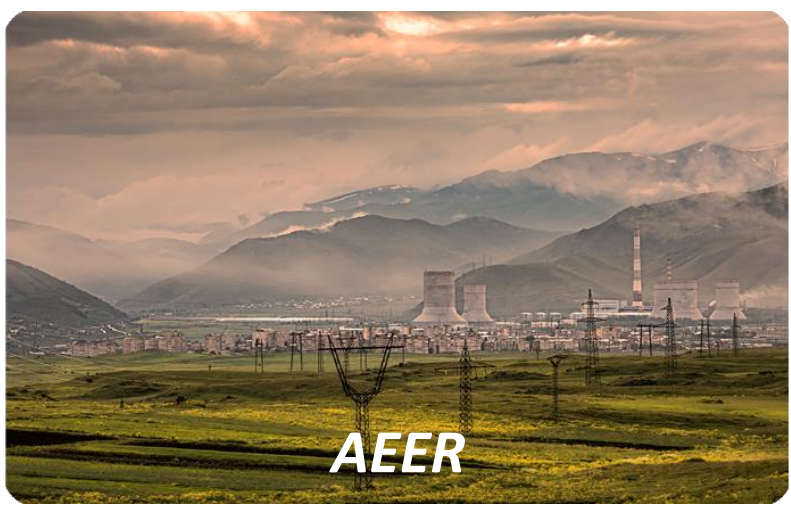

Enjoy $A E E R$ by:

1. Submitting a manuscript

2. Joining in volunteer reviewer bank

3. Joining Editorial Board

4. Guest editing a special issue

For more details, please visit:

http://www.lidsen.com/journals/aeer 